\title{
منهج المعلمي في التعليل بعلدم الاتصال
}

\section{الباحثتة/ ملال حهد عبد الآم المنزيا}

معيد بقسم التفسير والحديث - كلية الشريعة

جامعة الكويت - باحثة بمرحلة الدكتور اه

( تخصص الحديث الثريف وعلومهة)

جامعة الملك سعود - المملكة العربية السعودية

المقدمة:

الحمد لله رب العالمين، و الصلاة و السلام على أثشرف المرسلين سيدنا محمد وعلى آلــه

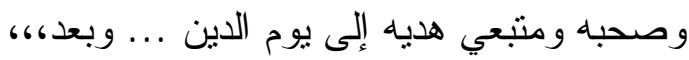

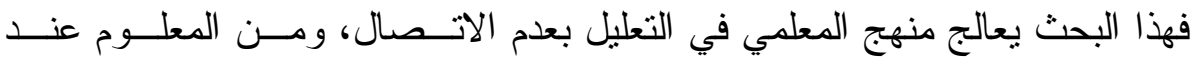

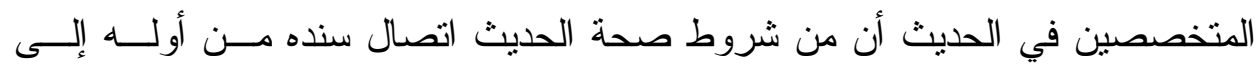

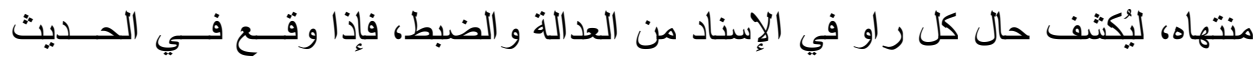

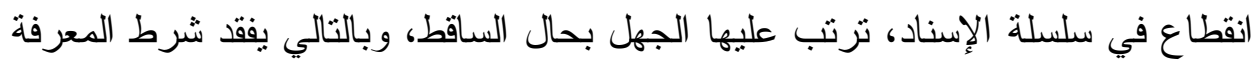
بعدالة وضبط الرواة، ولا يمكن الحكم بصحة الحديث.

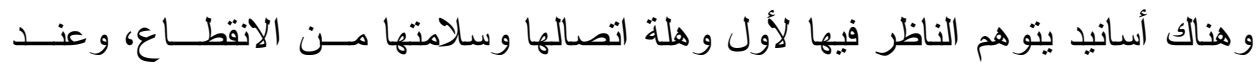

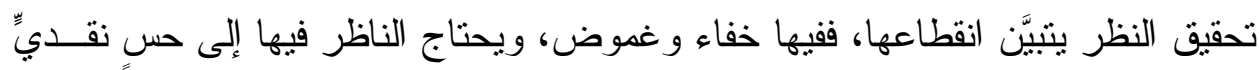

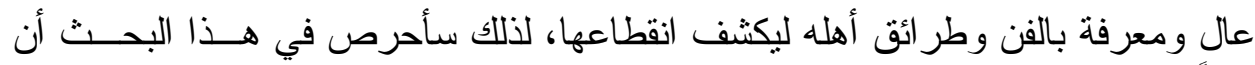

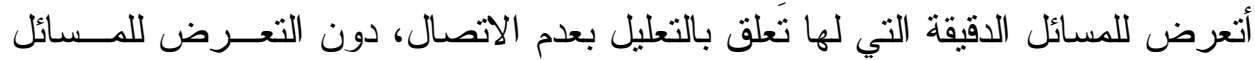

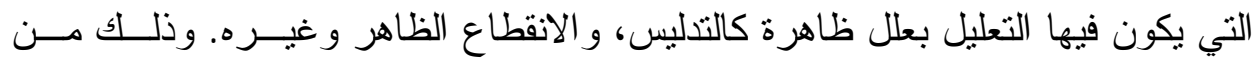
خلاص مؤلفات المعلمي في علم الحديث. وسوف أسير في هذا البحث وفق الخطة فئ التالية:

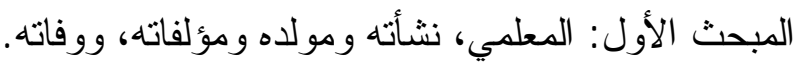

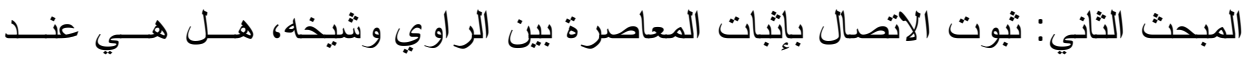
المعلمي نتأثر بالقر ائن في إثبات السماع و عدمه؟. 
المبحث الثالث: دخول الخطأ في التصريح بالسماع في الأسانبد المشكوك في اتــصالها،

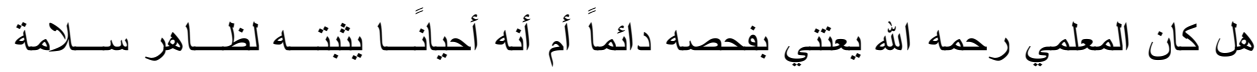
الأسانيد؟ إن. 
المبحث الأول: المعلمي، نشأته ومولاه ومؤلفاته، ووفاته.

اسمده ونسببه:

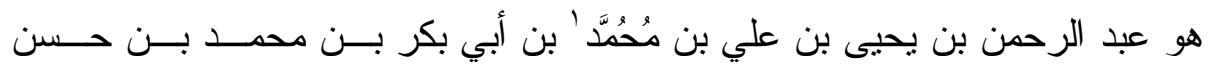

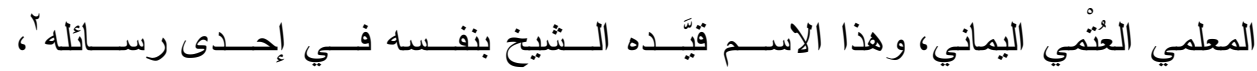

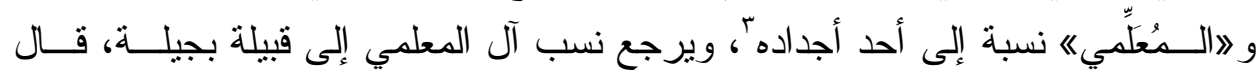
المعلمي رحمه الله: ابجيلة عك: بطن من بني عبس بن سمارة بن غالب بن عبد الله بن عك، منهم كما في طرفة الأصحاب: محمد بن حسين البجلي الصالح، وهو مشهور جدًّا

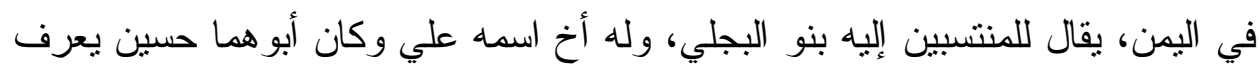

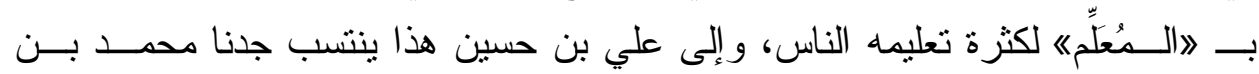

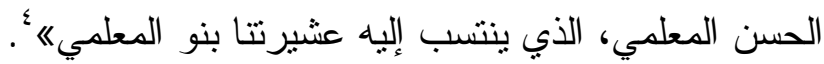

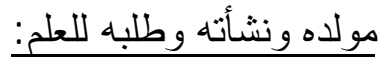

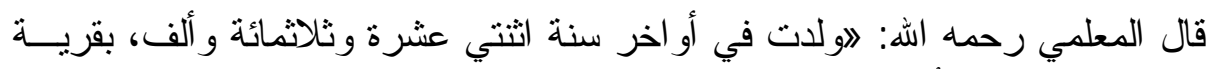

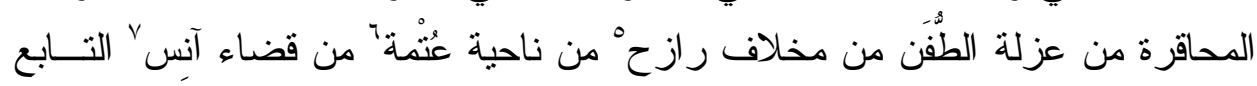
لو لاية صنعاء في اليمن«^.

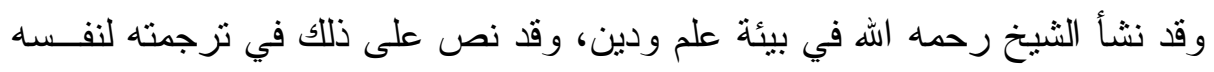

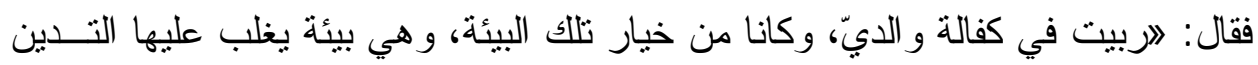
و الصلاح"

ا قال علي العمر ان : هكذا ضبطها الثيخ -أي المعلمي -. المدل إلى آثار الثيخ العلامة عبد الرحمن بن يحيـي المعلــي

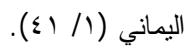

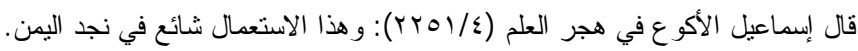

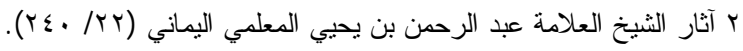

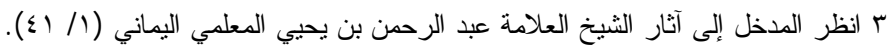

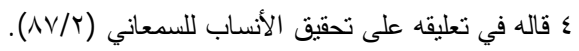

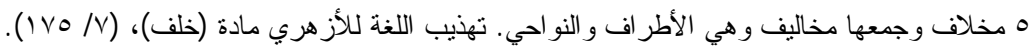

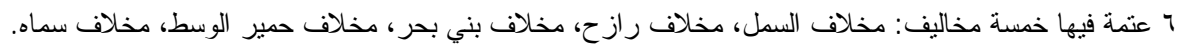

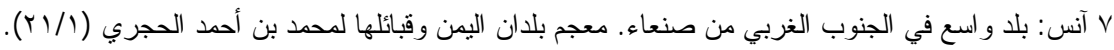

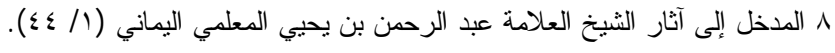

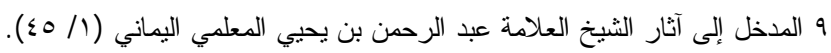


حفظه للقر آن:

وذكر الثيخ في ترجمته أنه بدأ بقر اعة القرآن على رجل من عثيرته، و على و الـــده

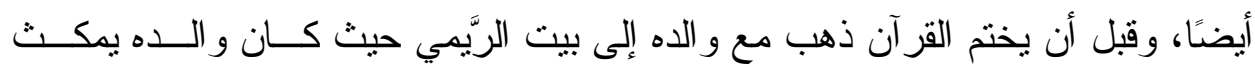

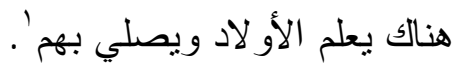

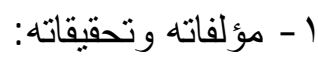

قبل أن تخرج كتب المعلمي رحمه الهه ورسائله المخطوطة التي وُجدت في مكتبة الحرم

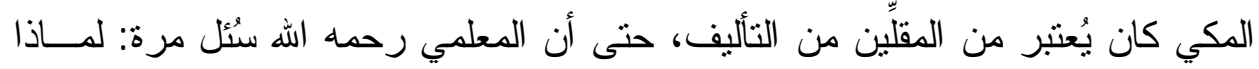

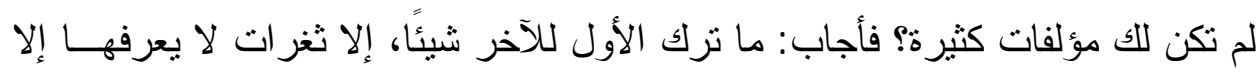

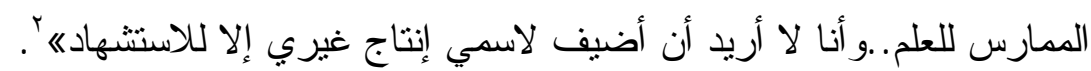

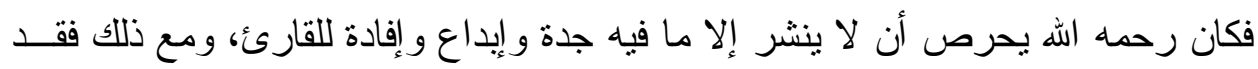

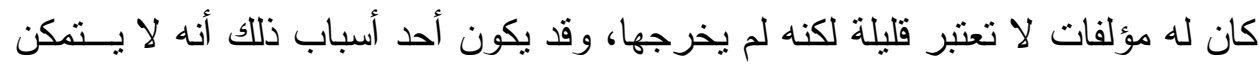

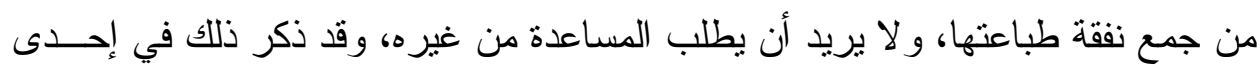

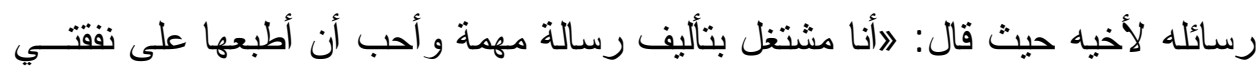

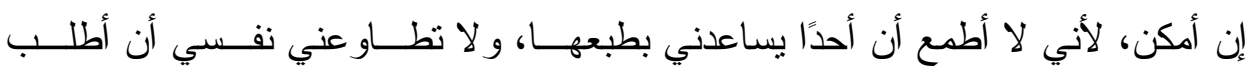

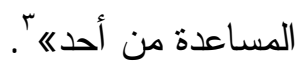

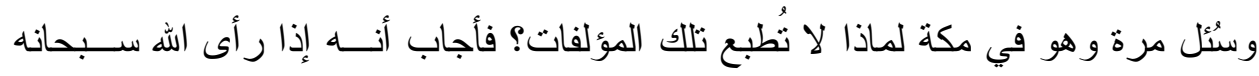

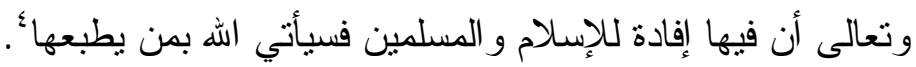

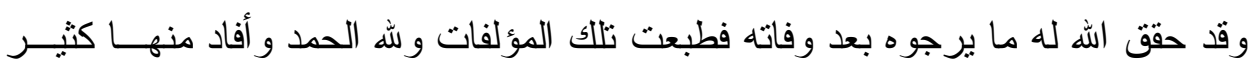
من الناس، وسأذكر في هذا الموضع بعض مؤلفاته مقسمة بحسب العلوم التــي تتتمــي إلبها: مؤلفاته في علم الحديث:

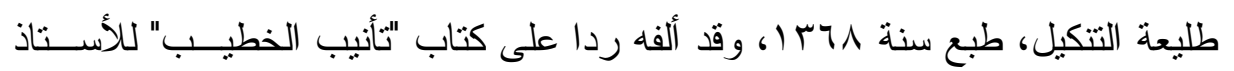
محمد ز اهد الكوثري.

ا انظر الدذخل إلى آثار الثيخ العلامة عبد الرحمن بن يحيي المعلمي اليماني (1/ / ؛ ).

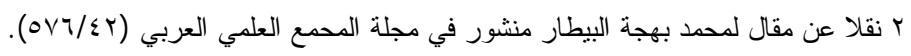

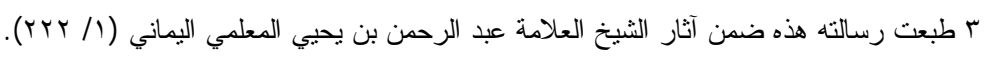

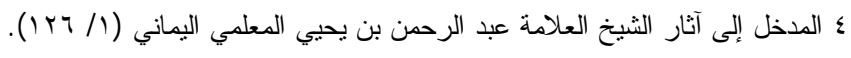




$$
\text { تعزيز الطليعة. }
$$

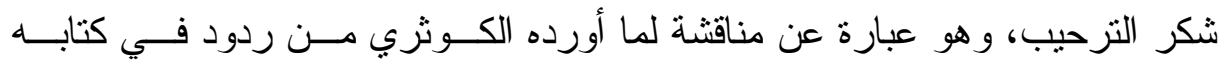
الترحيب على ما ذكره المعلمي في طليعة التنكيل.

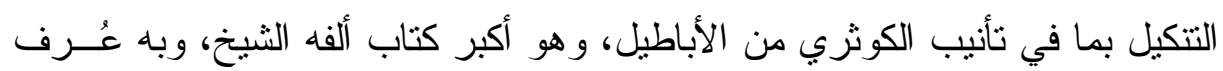
الثيخ عند كثير من المشتغلين في العلوم الثرعية.

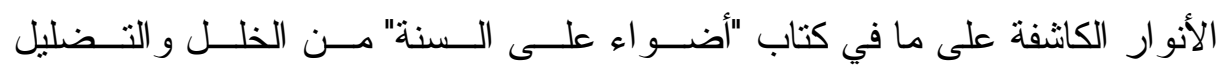

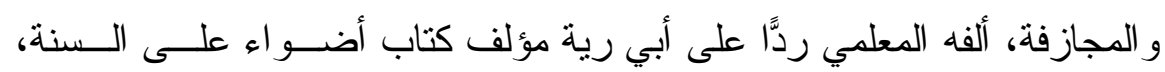

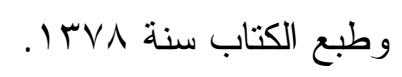

كتاب الوحدان، و الكتاب عبارة عن مسودة.

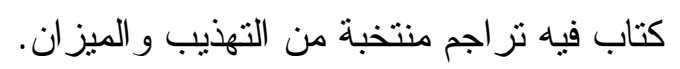

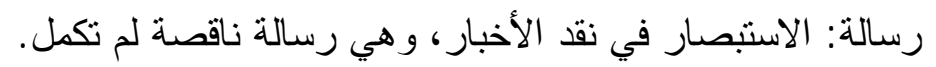

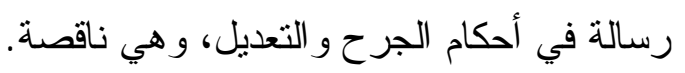
رسالة في الحاجة إلى معرفة علم الجرح و التعديل .

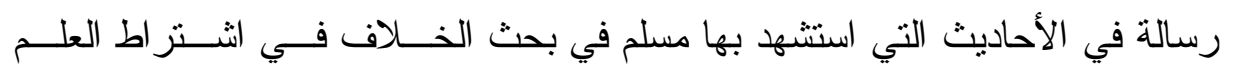
باللقاء.

رسالة في الصيغ المحتملة للتدليس، أظاهرة هي في السماع أم لا؟، و الرسالة ناقصة.

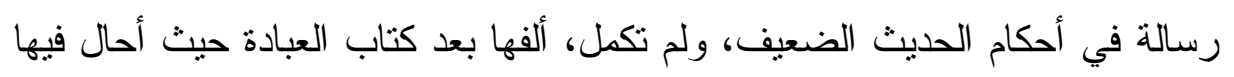
على الكتاب. محاضرة في علم الرجال و أهميته، وهي عبارة عن محاضرة ألقاها المؤلف في لقــاء

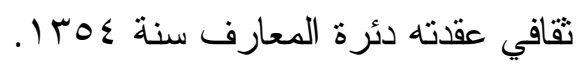
تنزيه الإمام الثافعي عن مطاعن الكوثري.

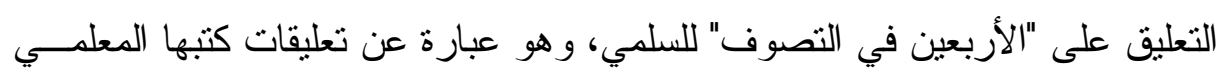

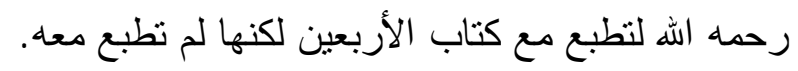

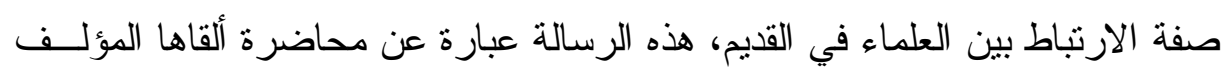

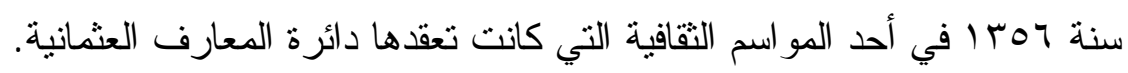


تحقيقاته :

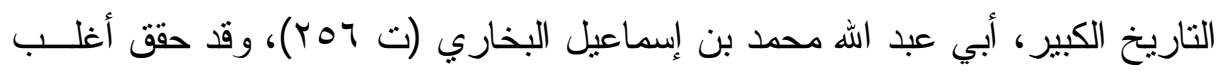

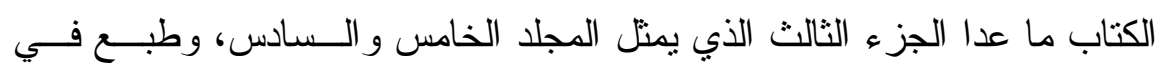

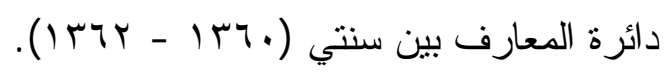

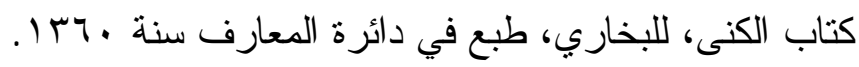

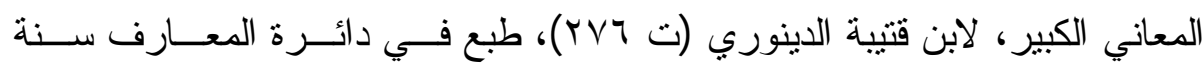
.1179 - 114

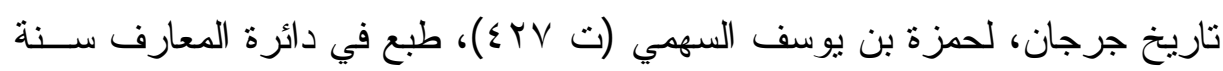
.

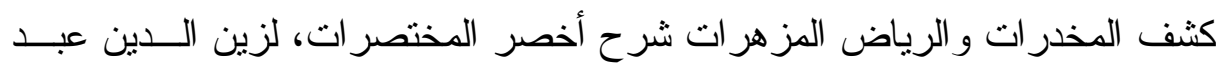

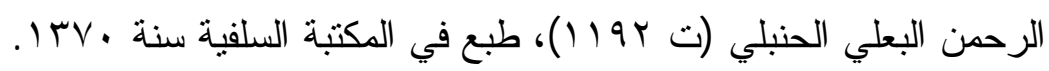

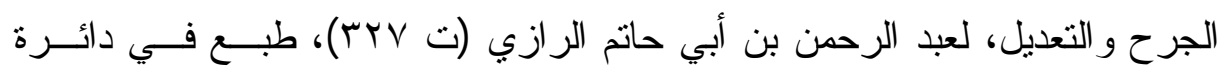

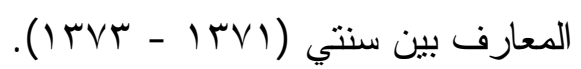

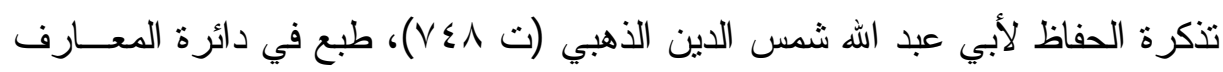
بين سنتي ITV - ITV

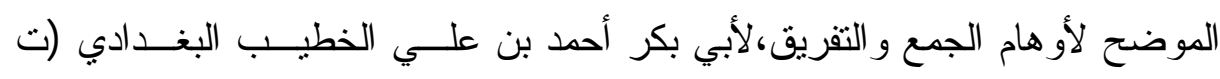

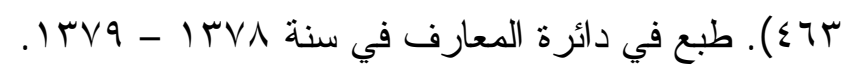

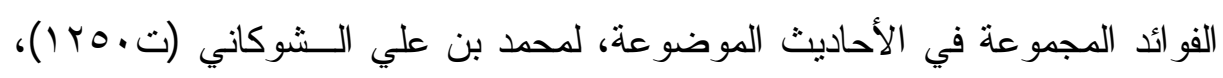

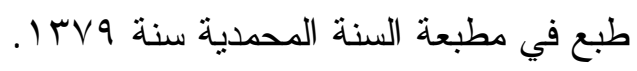

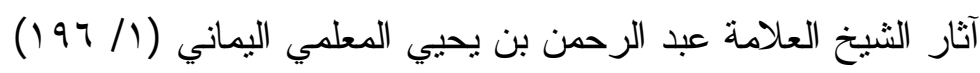

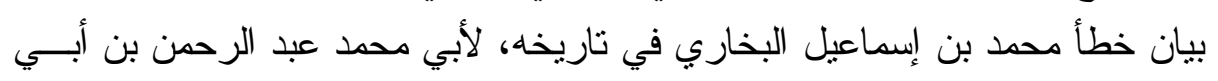

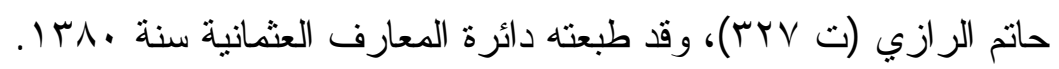

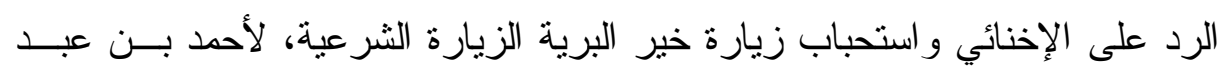

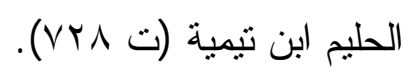

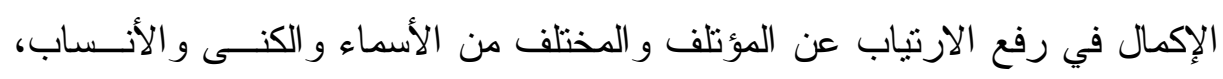

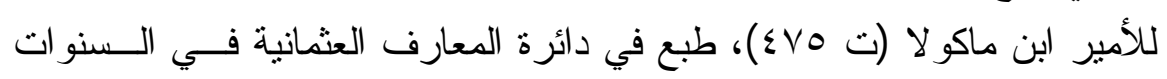

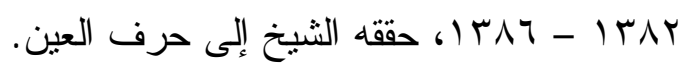


الأنساب، لأبي سعد عبد الكريم بن محمد الـسمعاني (ت ب7ه)، طبـع فـي دائـرة

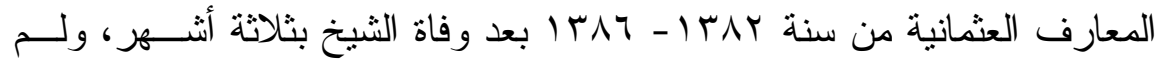
يكمل الثيخ تحقيقه .

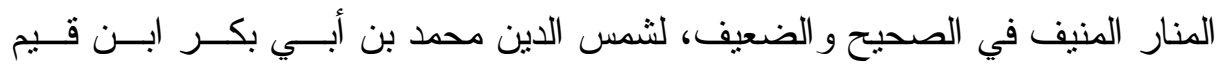

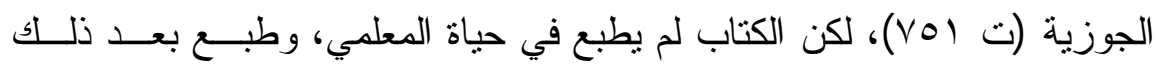

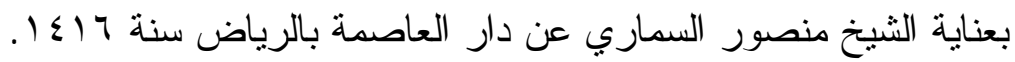
و هناك كتب شارك في تحقيقها، منها:

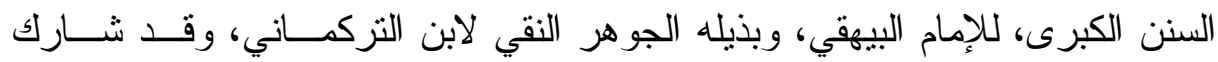

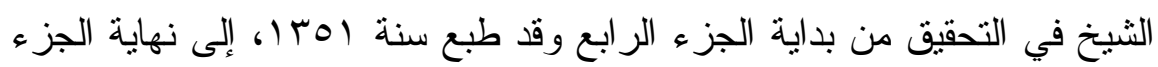

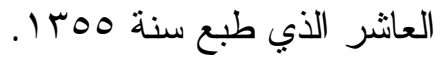

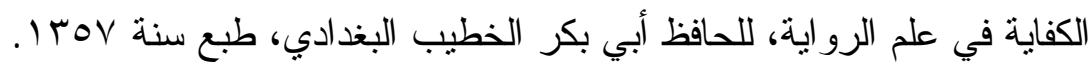

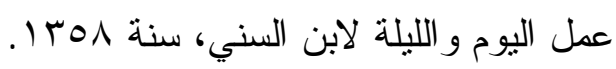

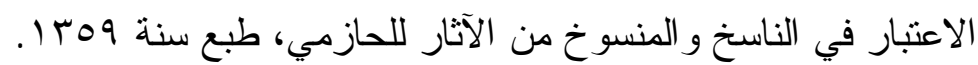

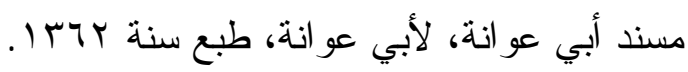

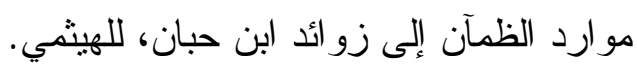

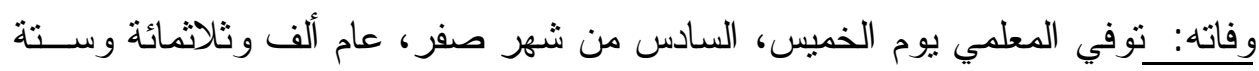

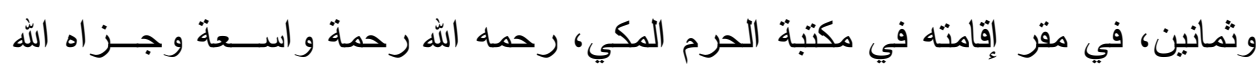

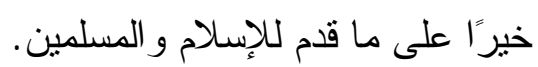


المبحث الثاني: ثبوت الاتصال باثبات المعاصرة بين الر اوي وشبخه، هل هي عند

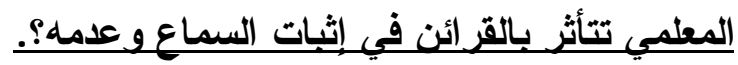

سأتناول في هذا المبحث نقطتين:

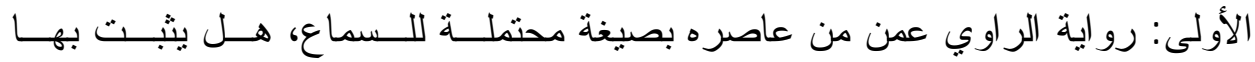

الاتصال.

الثانية: هل و افقت تطبيقات المعلمي ما قرره نظريَّا في مسألة ثبوت المعاصرة و إمكــان

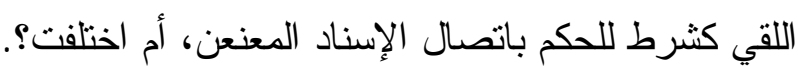

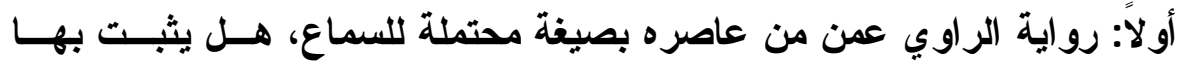

\section{الاتصال:}

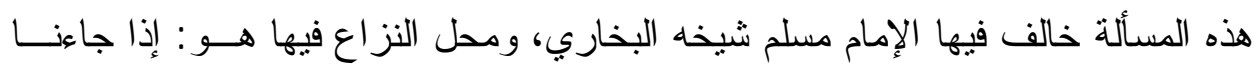

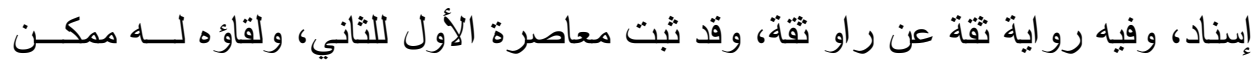

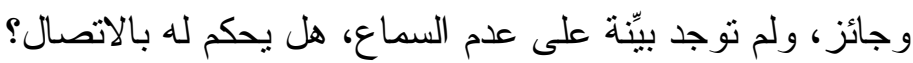

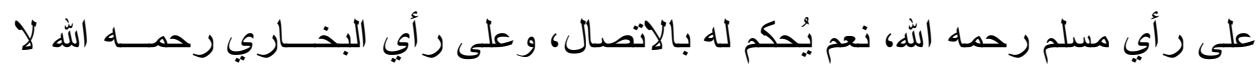

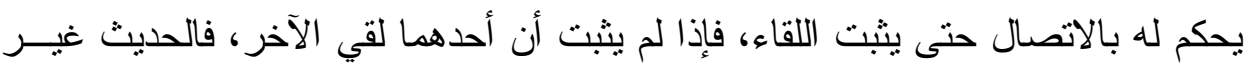
متصل.

و السبب في إير ادي لهذه المسألة هو بيان رأي المعلمي رحمه الله فيها من جهة التتظير،

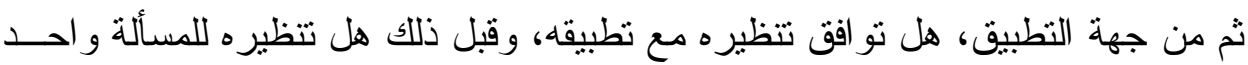

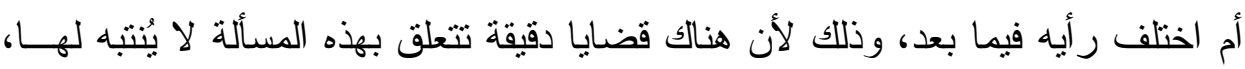

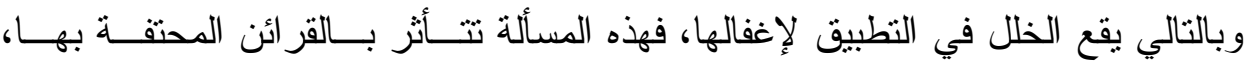

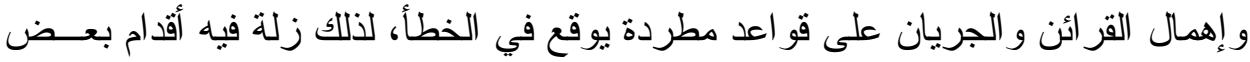

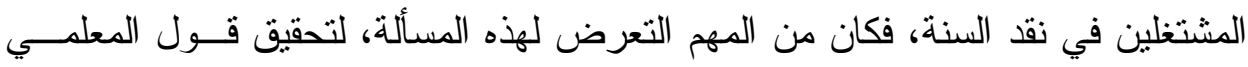
رحمه الله فيها، ثم النظر في تطبيقاته هل و افقت قوله في المسألة أم خالفته، و الله أســأل التيسير و التسديد.

الثانية: هل و افقت تطبيقات المعلمي ما قرره نظريَّا في مسألة ثبوت المعاصرة و إمكــان

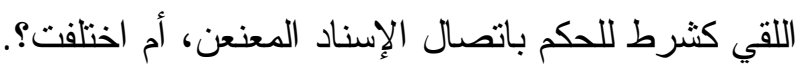

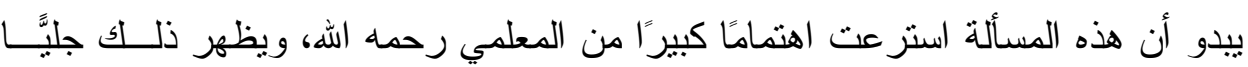

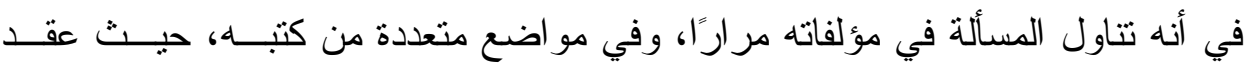




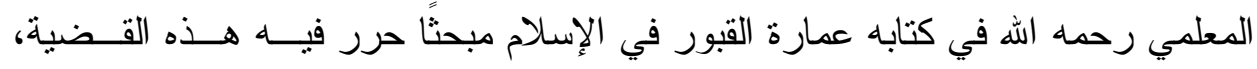

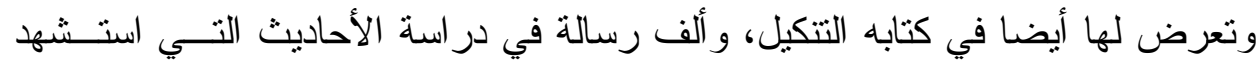

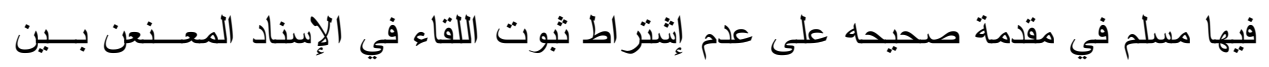

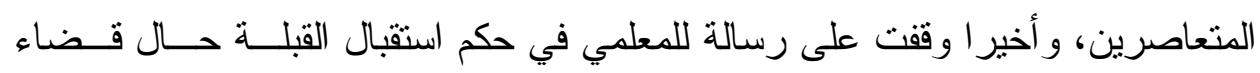

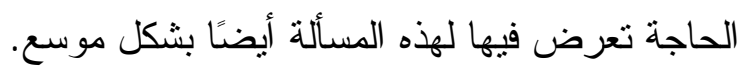

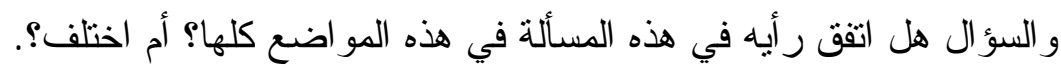

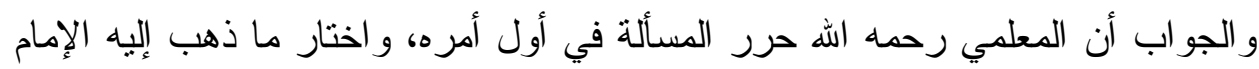

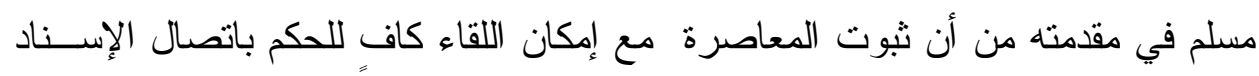

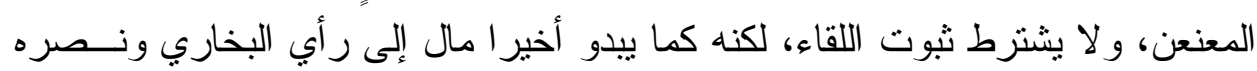

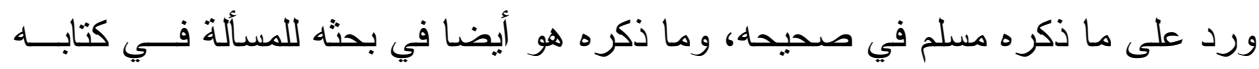

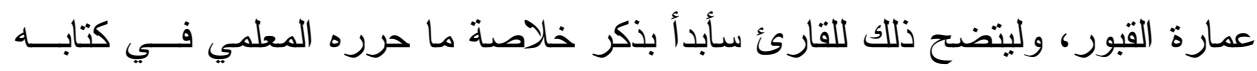

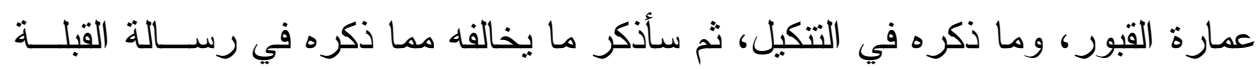
وقضاء الحاجة.

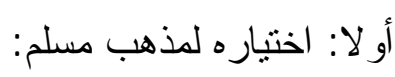

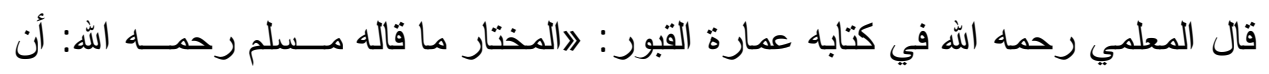

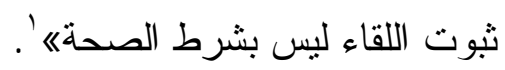
وقد فصَّل المعلمي رحمه الله في توضيح ما ذهب إلبه حيث ذكر أن الأصل في روايـــة

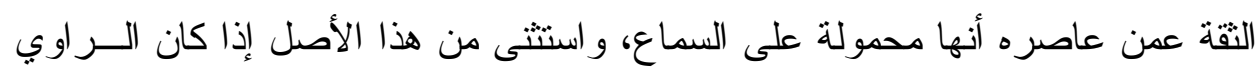

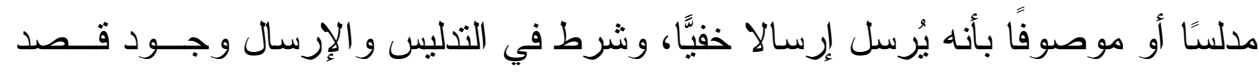

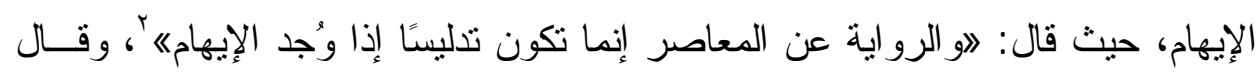
في التتكيل: اوصنيع مسلم يقتضي أن الإرسال على أي الوجهين كان إنما يكون تدليسًا

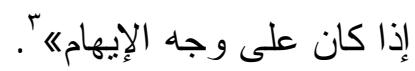

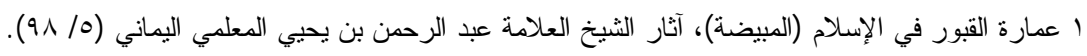

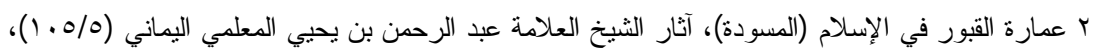

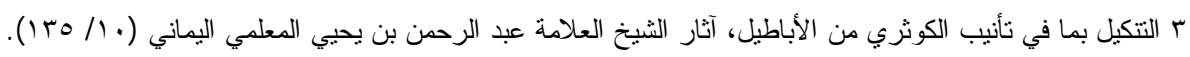


واستثنى أيضًا من هذا الأصل وجود نص من أحد رجال السند أو من غيرهم على عدم اللقاء'

وذكر في موضع آخر أن هذا الأصل ينأثر بالقر ائن، فقال: الوا الحاصل أن الأصل كمـــا

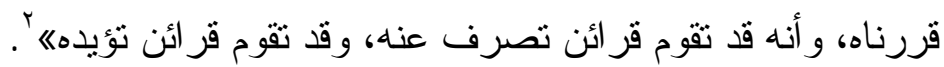

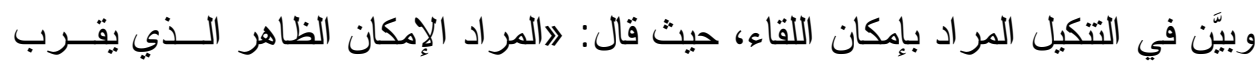

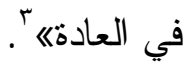
وقال: إإن كان اللقاء مستبعدًا، الظاهر عدمه، فلا وجه للحمل على السماع، لأن ظهور

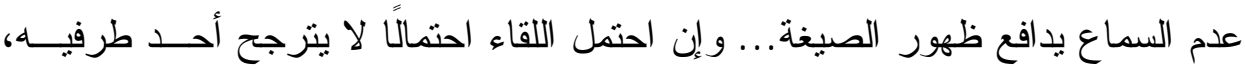

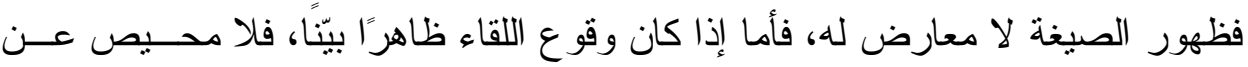

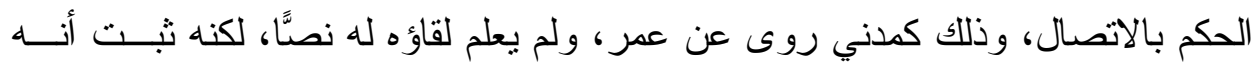

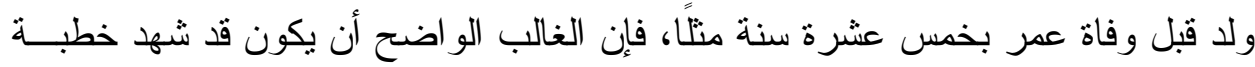
عمر في المسجد مر ارًا. فأما إذا كان الأمر أقوى من هذا، كرا، كرواية قيس بن سعد المكي عن عمرو بن دينار ، فإنه

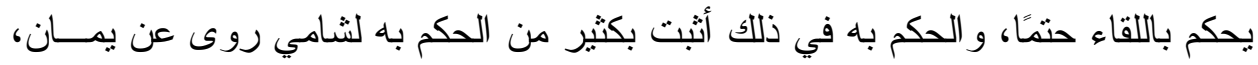

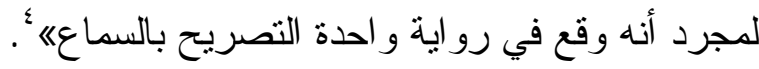
فيلاحظ في كلامه رحمه الله أنه يحكم بالاتصال :

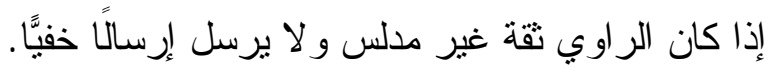

$$
\text { ثبوت المكان اللقاء. }
$$

وشرط للحكم بالاتصال عدم وجود نص من رجال السند أو غير هم على عـدم اللقــاء،

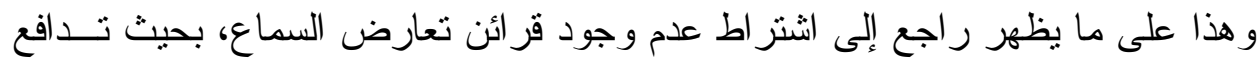

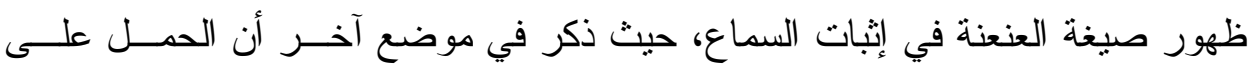

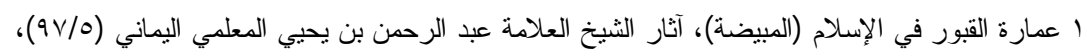

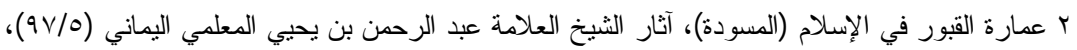

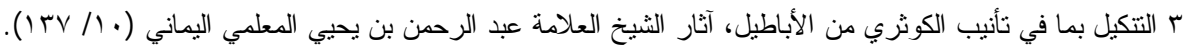

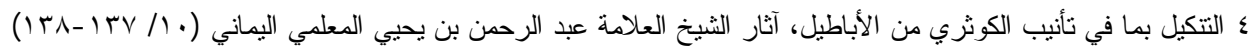


السماع مشروط بعدم وجود بينة على عدم السماع'، ثم منَّل للبيّنة جبما في مسند أحمــد :

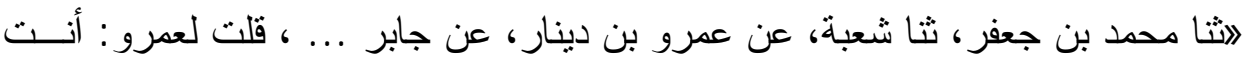

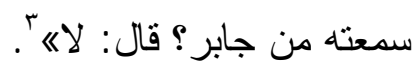

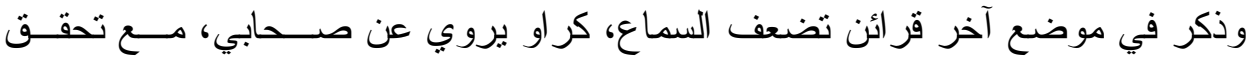

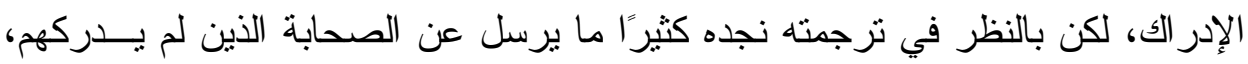

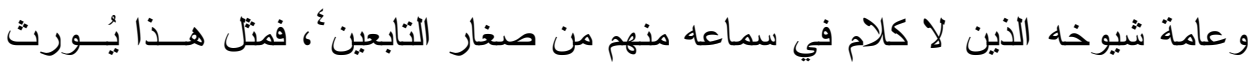
ريبة في الحكم باتصاله .

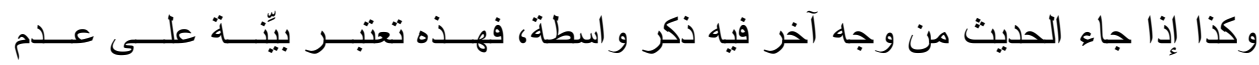

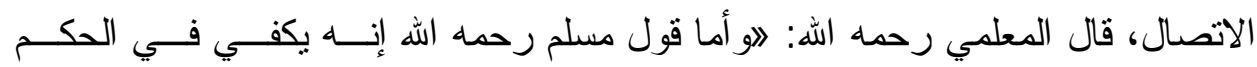

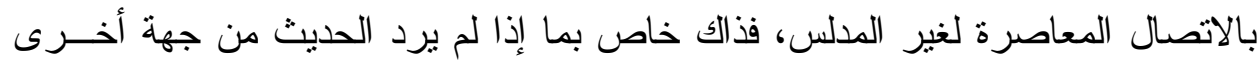

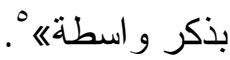

ثانيا: تغير اجتهاده، واختياره لرأي البخاري في المسألة:

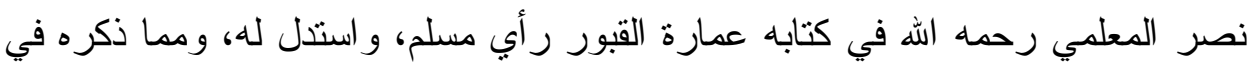

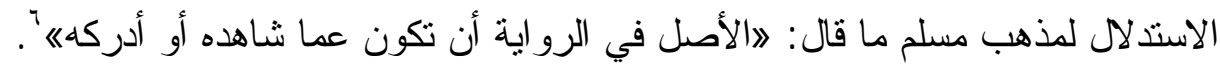

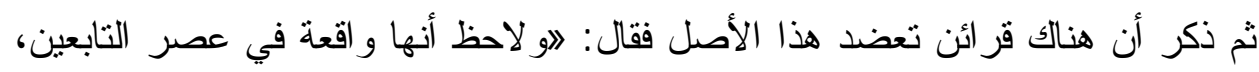

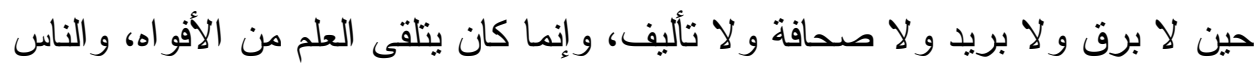

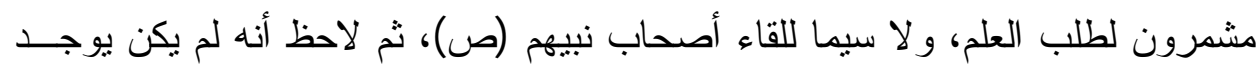

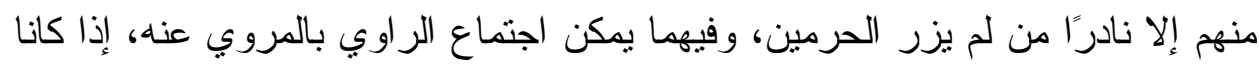

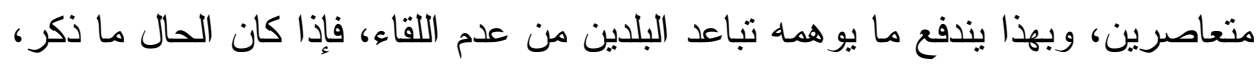

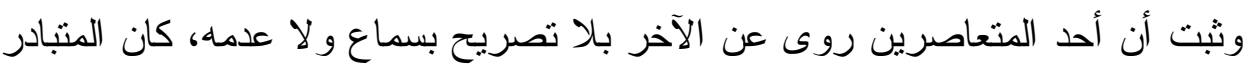

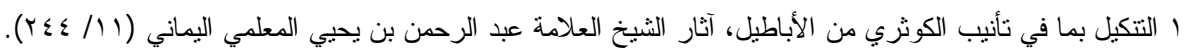

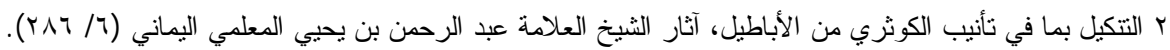

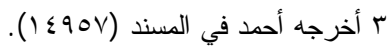

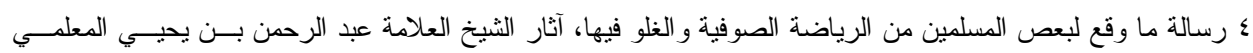

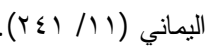
ه مسائل القر اءة في الصلاة والرد على أحد شر اح التزمذي، آثار الثيخ العلامة عبد الرحمن بن يحيي المعلمي اليماني (1) 
السماع، فكيف إذا لاحظت أن كثيرًا من السلف كان يزور الحرمين كل عام، فكيــف إذا

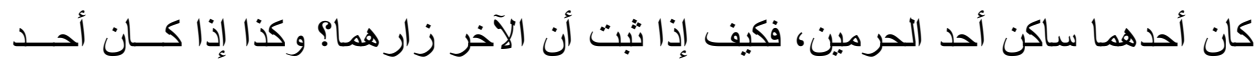

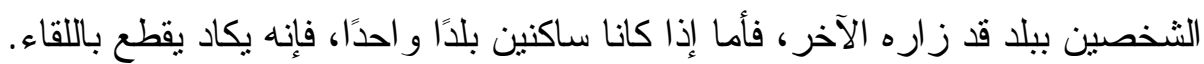

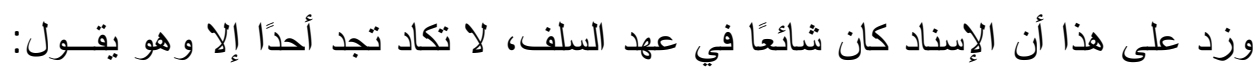

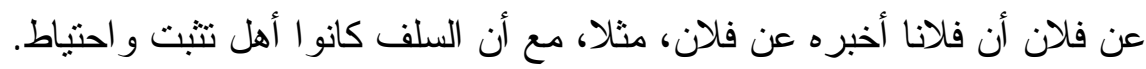

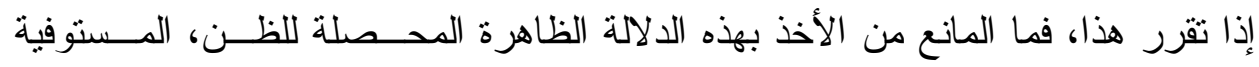

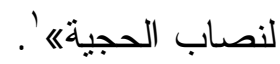
وخلاصة دليله أن الأصل في رواية الثقة غير المدلس عن شيخه أنها محمولــة علـىى

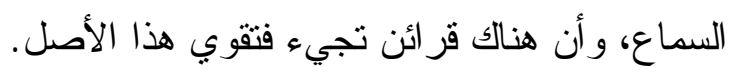

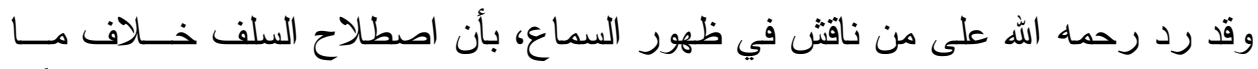

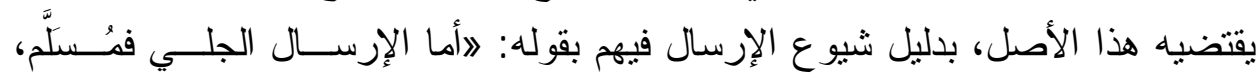

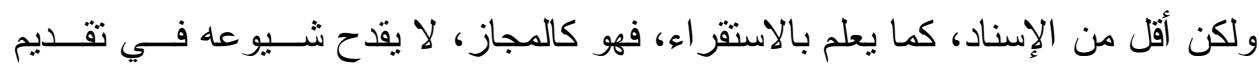

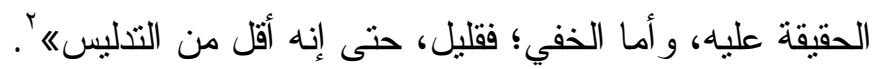
وقد رد بنفسه على كلامه هذا برسالته الأخرى في القبلة وقضاء الحاجة، بأن إثبات هذا

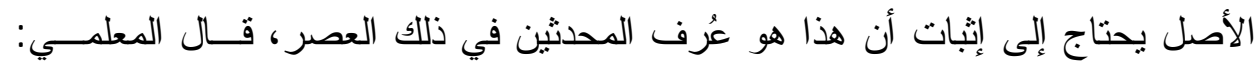

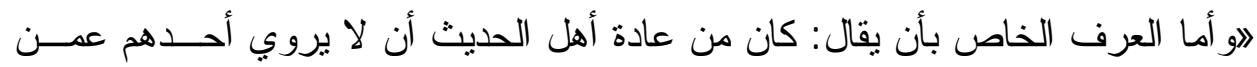

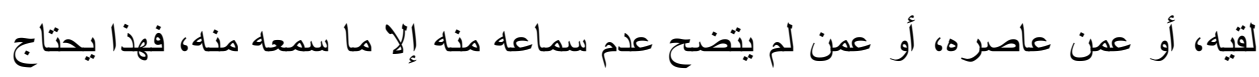

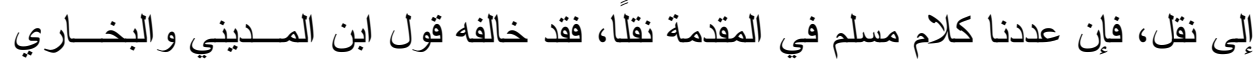

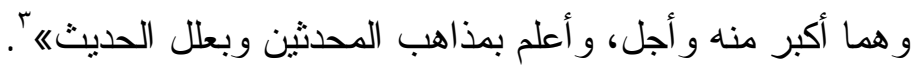

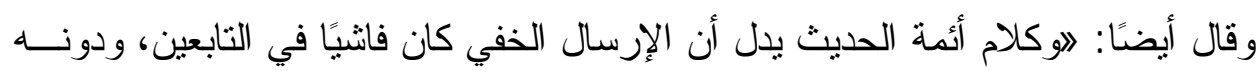

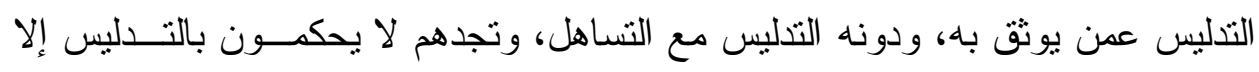

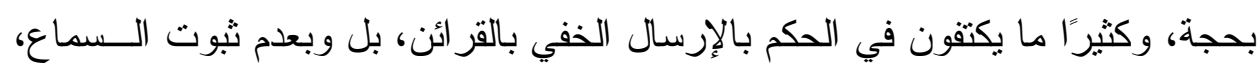

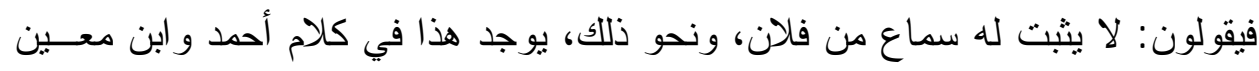

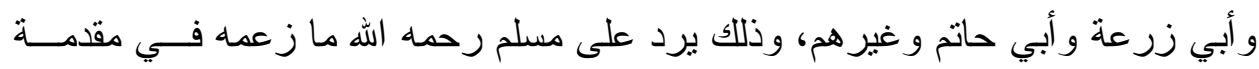

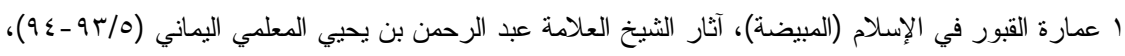

r عمارة القبور في الإسلام (المبيضة)، آثار الثيخ العلامة عبد الرحمن بن يحيي المعلمي اليماني (10 ع ؟ 9).

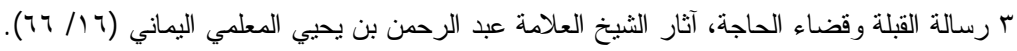


صحيحه من أن قول البخاري محدث، ويدل دلالة و اضحة أنه كان عندهم أنه لا يكــون

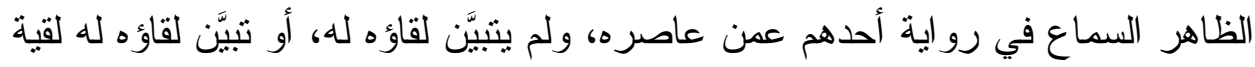

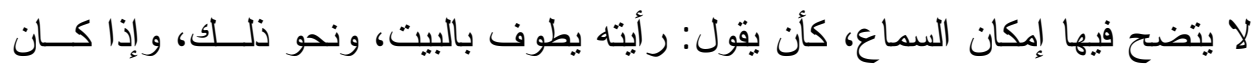

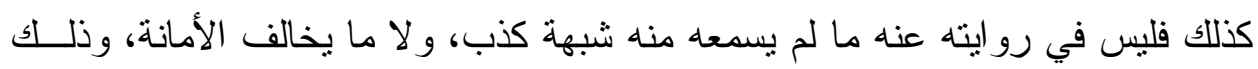

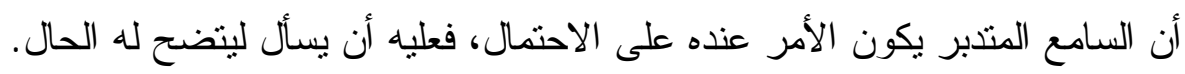

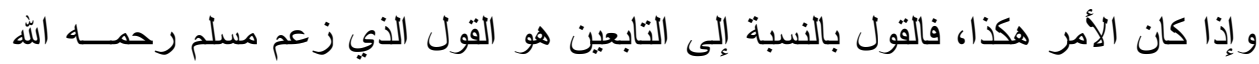

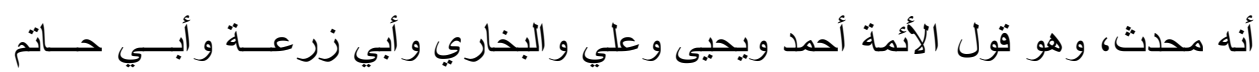

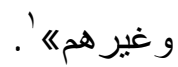

وقد ضرب في رسالته عمارة القبور أمثلة من و اقعنا تبيّن أن رواية الــر اوي بالعنعنــة

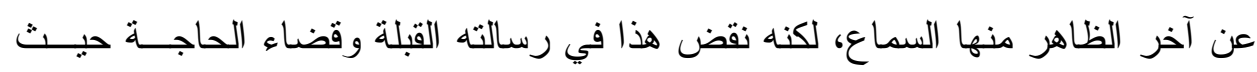

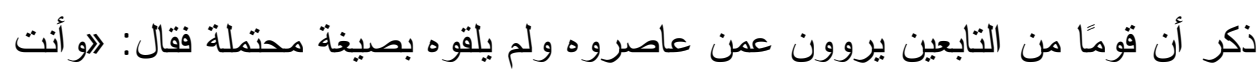

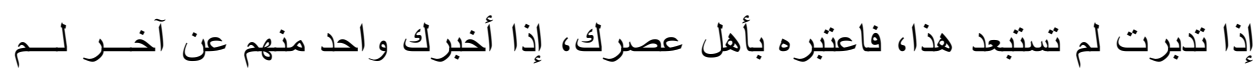

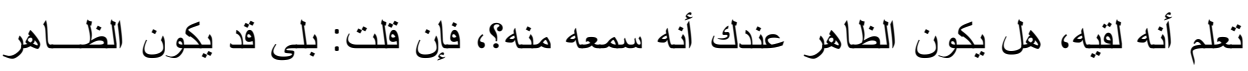

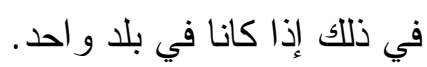
قلت: أنعم النظر وكثر الأمثلة، فإنانك تجد أنه لا يظهر السماع حتى يكون الظاهر اللقاء،

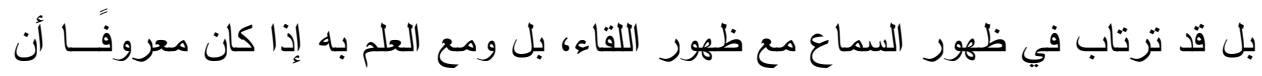

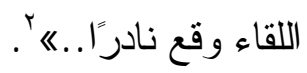

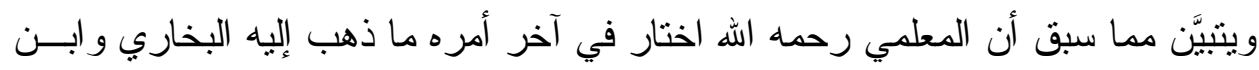

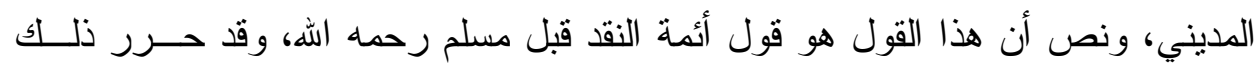

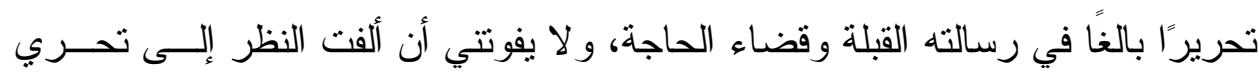

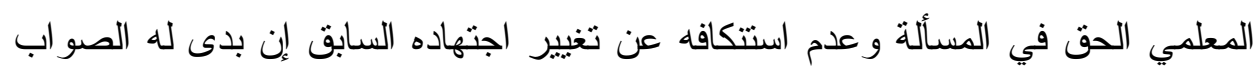

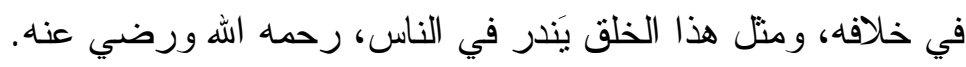
ويمكن إرجاع السبب الذي دعاه إلى اختبار رأي مسلم رحمه الله إلى أمرين، وهما: 
شيوع هذا الر أي في المتأخرين، قال ابن رجـب : لوكثيــر مــن العلمــاء

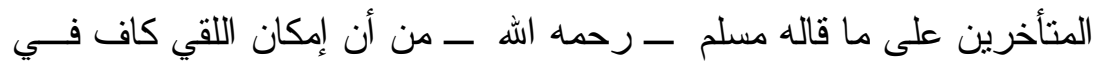

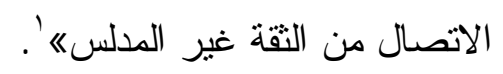
عدم اطلاعه على الكتب المتقدمة لأئمة الفن، فال إبر اهيم الصبيحي في بيان

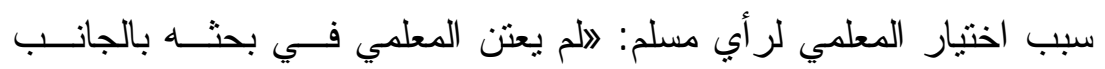

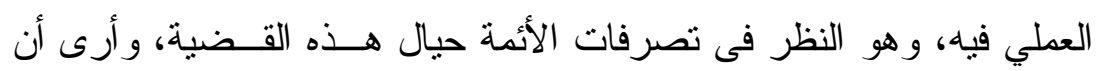

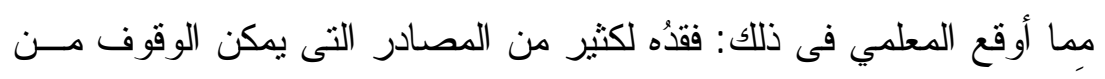

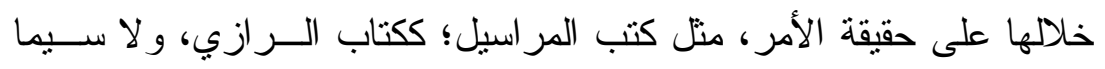

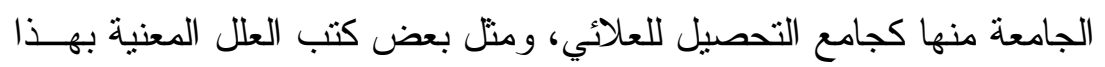

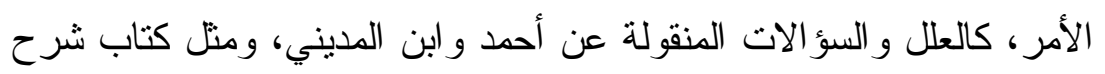

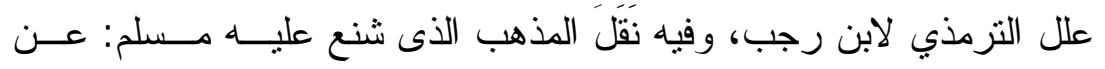

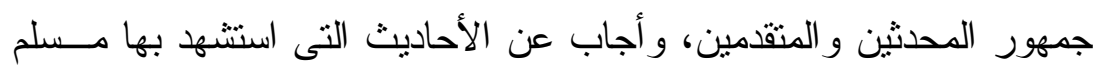

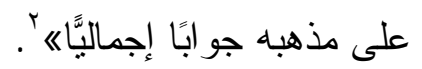

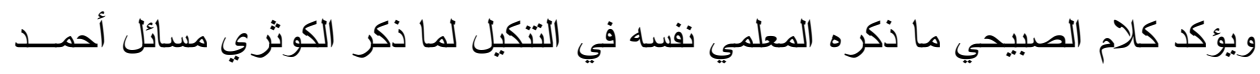

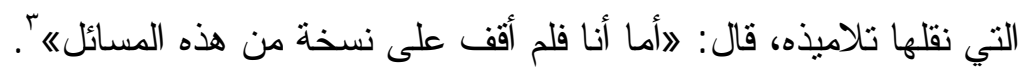

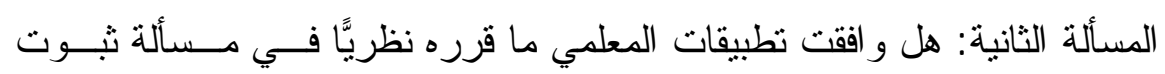

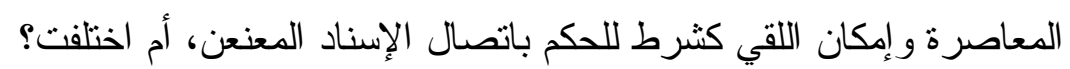

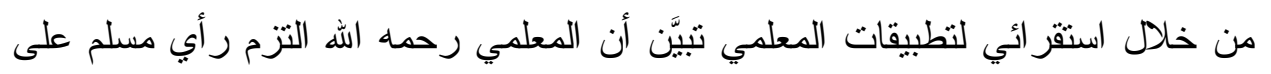
وجه العموم، إلا في مسألة اعتبار مجيء الحديث من وجه آخر فيه ذكر و اســة دلئل على الانقطاع، حيث اضطرب رأيه في در اسة بعض الأحاديث التي وققت عليها.

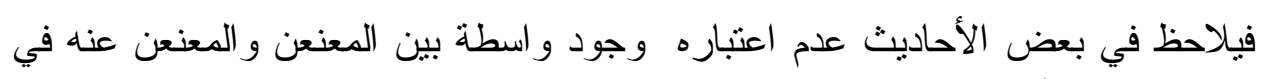

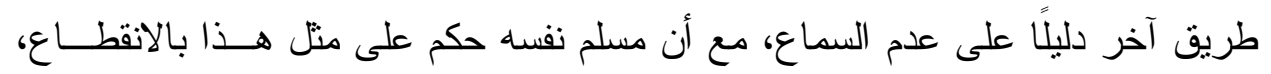

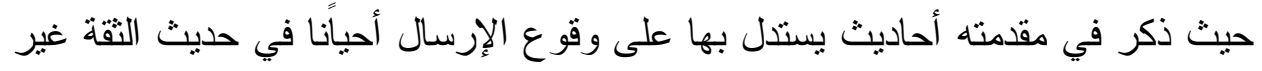

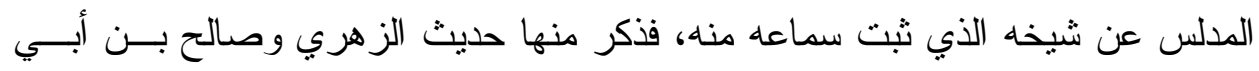

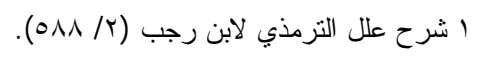

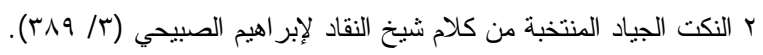

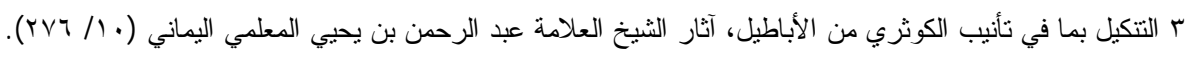


حسان عن أبي سلمة، عن عائشة (رض): لاكان النبي (ص) يُقبل وهو صائم"'، فقــال

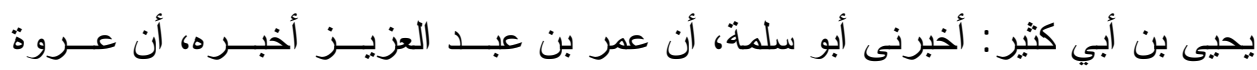

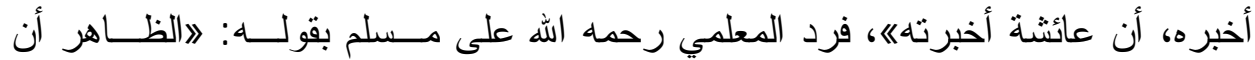

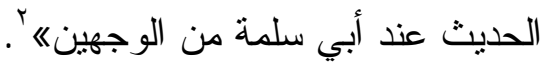

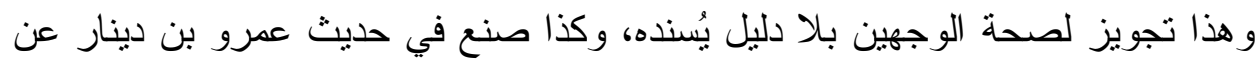

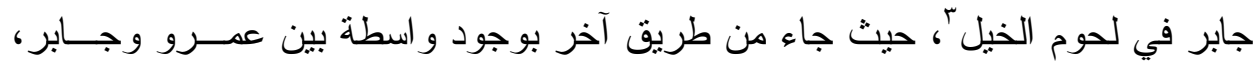

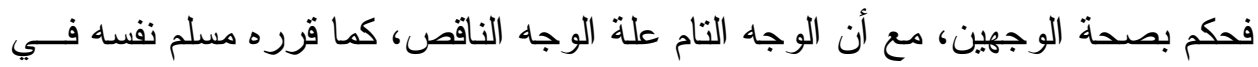

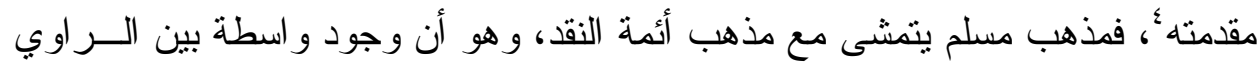

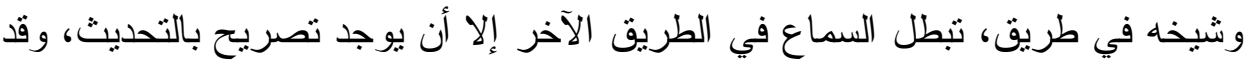

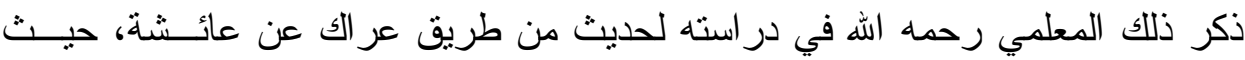

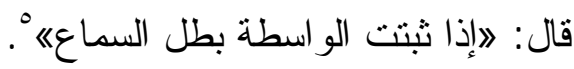

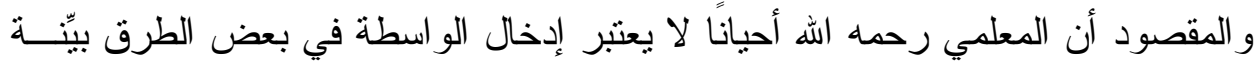

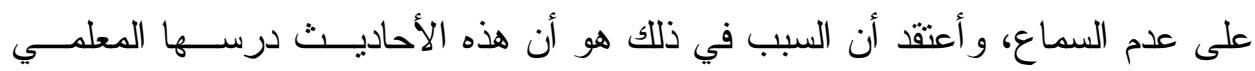

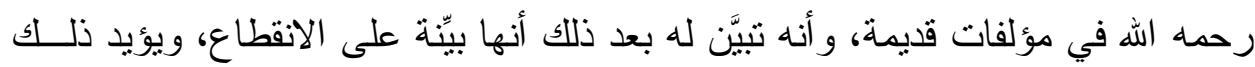

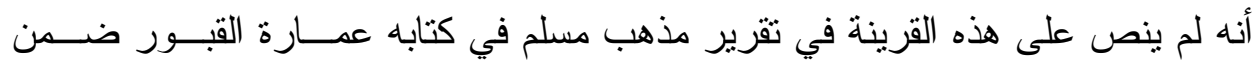

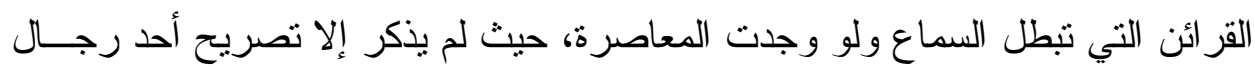
السند أو غيرهم على عدم السماع.

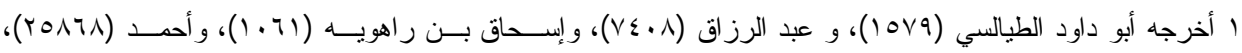

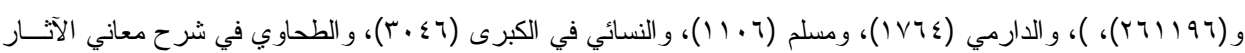

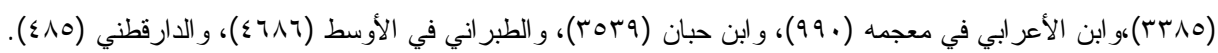

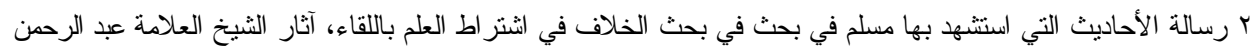

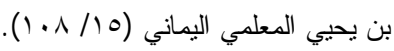

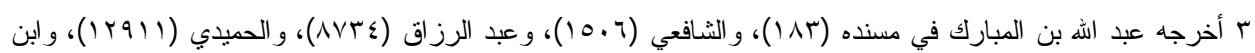

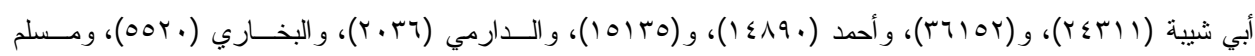

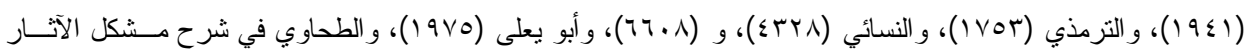

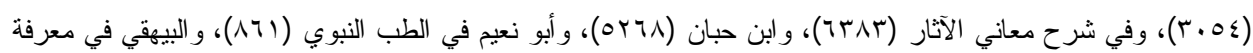

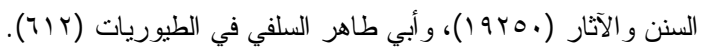

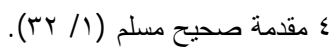
0 رسالة القلبة وقضاء الحاجة، آثار الثيخ العلامة عبد الرحمن بن يحيي المعلمي اليماني (17 م ه). 
ولذلك تجده في كتاب عمارة القبور نفسه يصحح حديث علي : أبعتُك على مــا بعثتـي

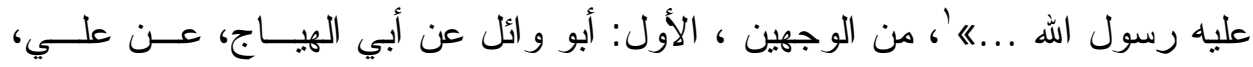

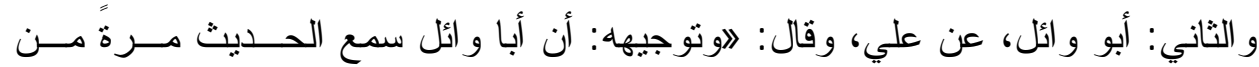

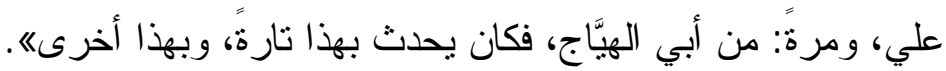

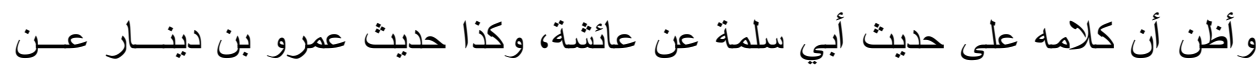

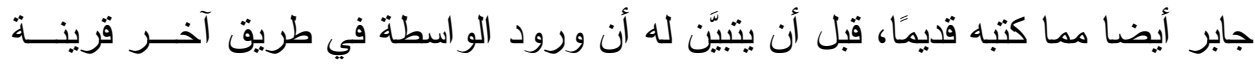

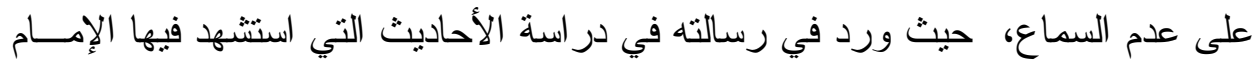

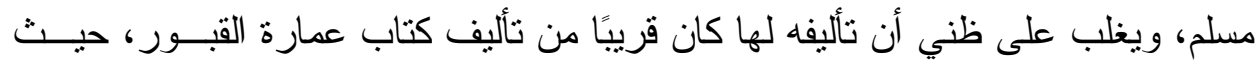

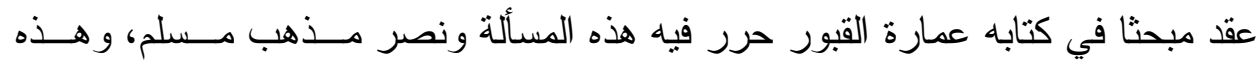
الرسالة تصب في المقصد نفسه . ومما يقوي هذا أنه في رسائله الأخرى أعلَّ بهذه القرينة، حيث أنثار في كتابه التنكيـلـل

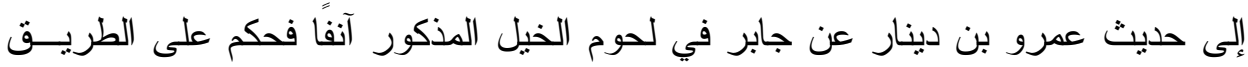
الذي لم يذكر فيه و اسطة بالإرسال .

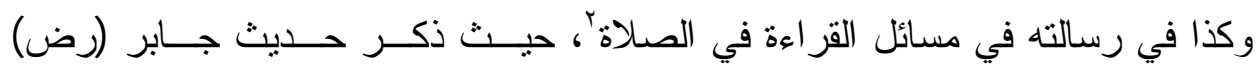

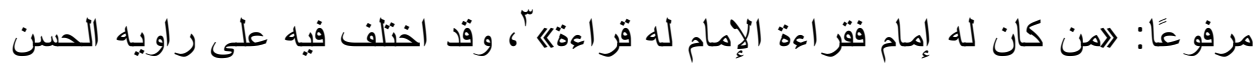

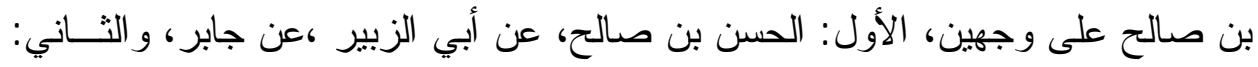

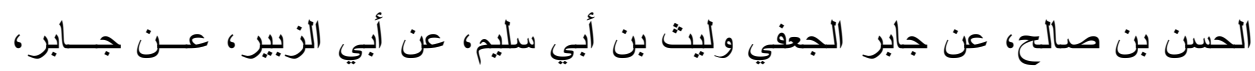

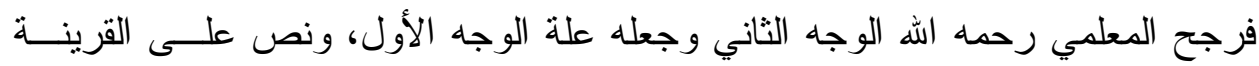

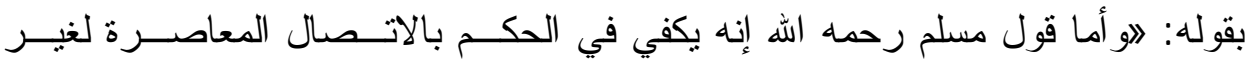

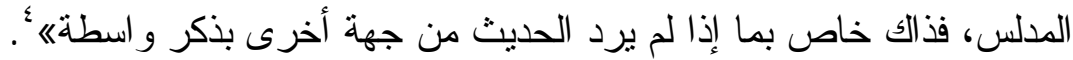

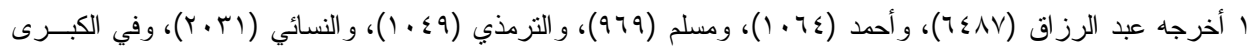

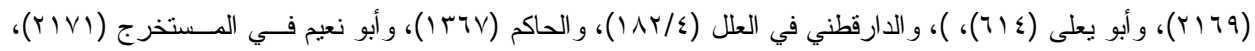

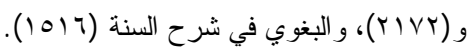

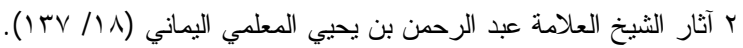

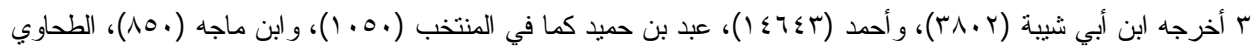

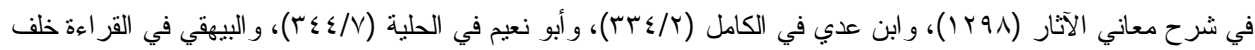

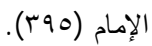

ك مسائل القر اءة في الصلاة و الرد على أحد شر اح الترمذي، آثار الثيخ العلامة عبد الرحمن بن يحيي المعلمي اليماني (1) 
وفي كتابه الوحدان ذكر حديث سمرة بن جندب (رض) مرفوعًا: اإن صاحبكم محبوس

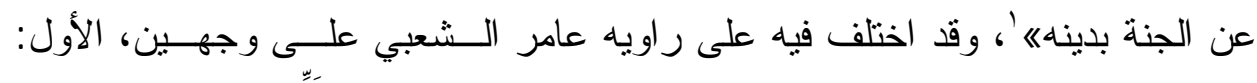

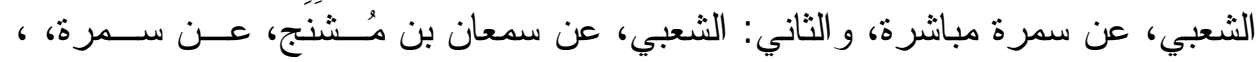

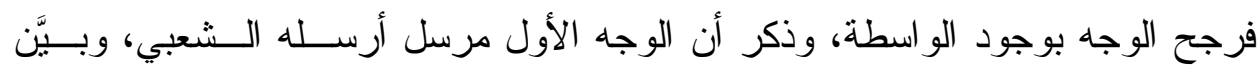
الو اسطة في الوجه الثاني.

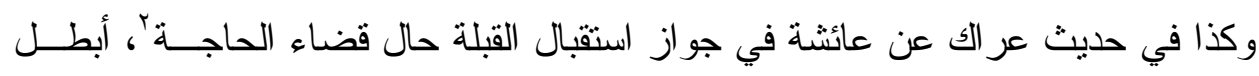

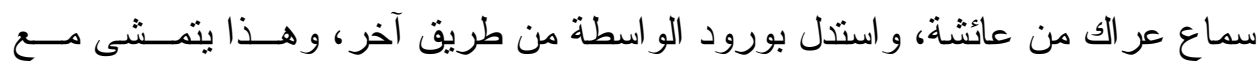

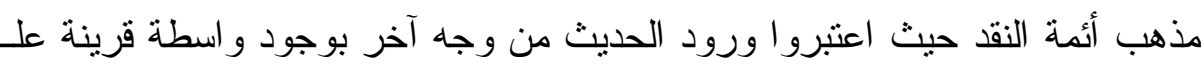

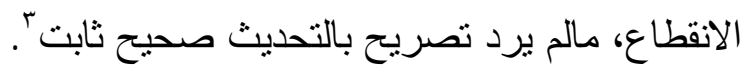

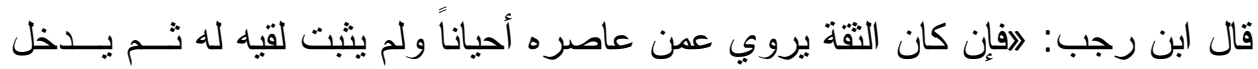

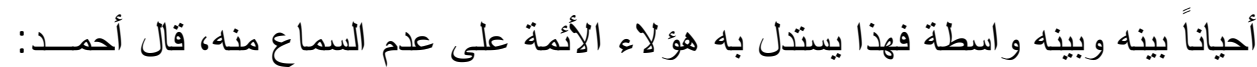

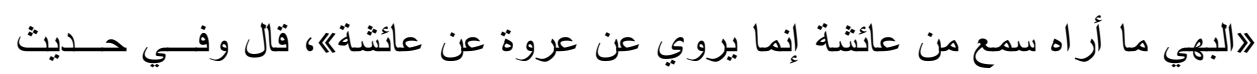

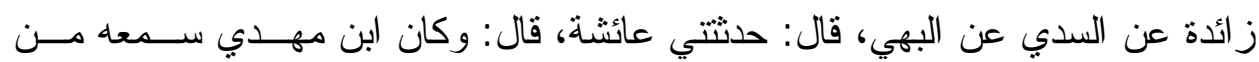

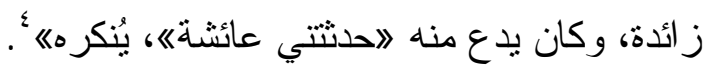

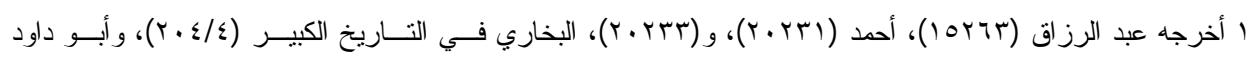

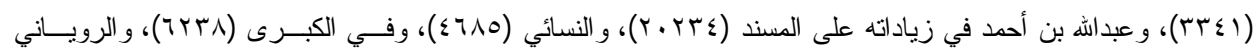

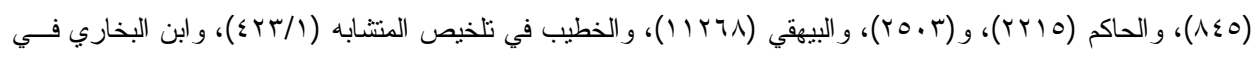

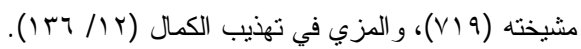

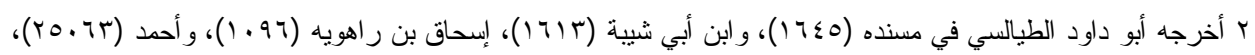

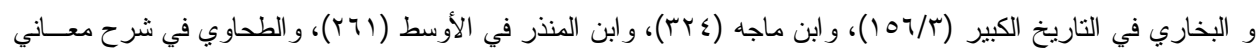

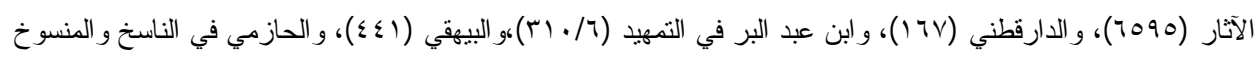

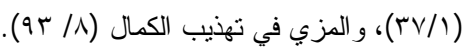

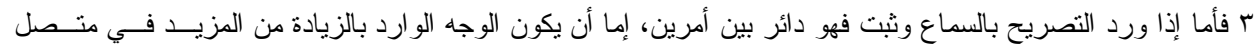

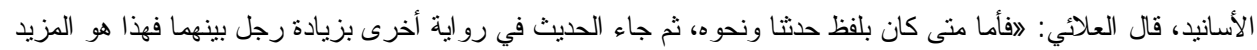

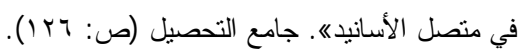

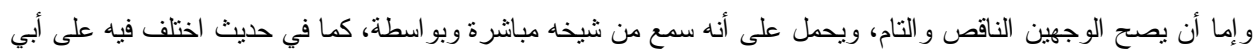

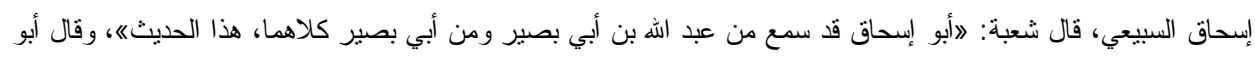

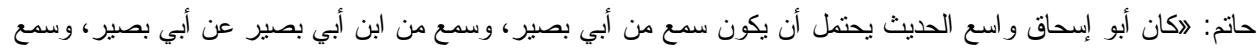

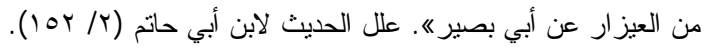

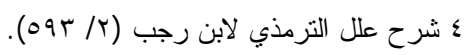


المبحث الثالث: دخول الخطأ في التصريح بالسماع في الأسانيد المشكوك في اتـصالها،

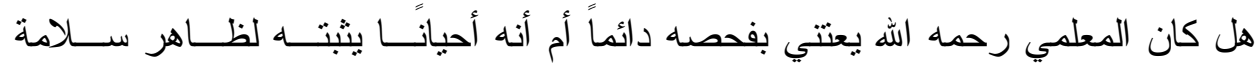

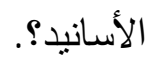

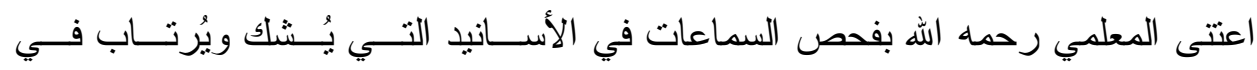
اتصالها، في غالب ما وققت عليه من الأحاديث في هذه القضية، وكان رحمه الله يستدل

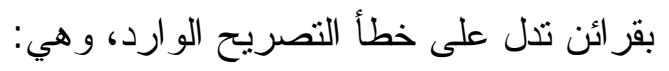
ا ـ وجود و اسطة في بعض الطرق في الحديث نفسه، أو في حديث آخر .

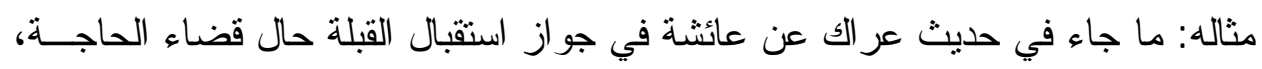

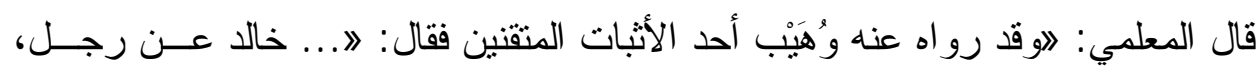

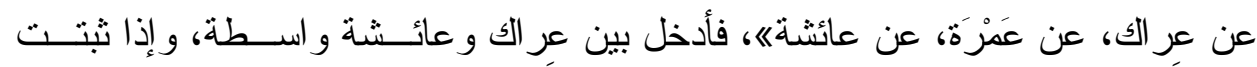
الو اسطة بطل السماعه' '.

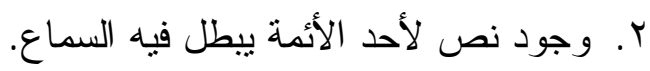

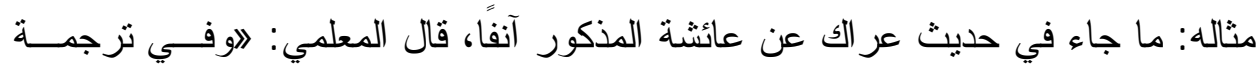

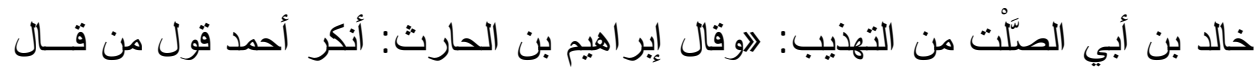

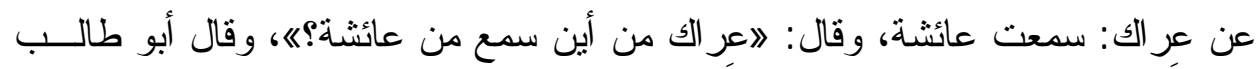

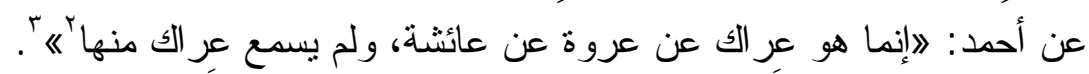

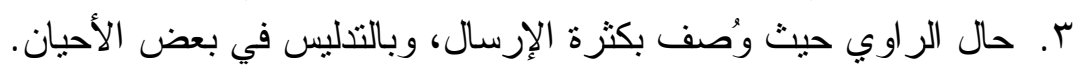

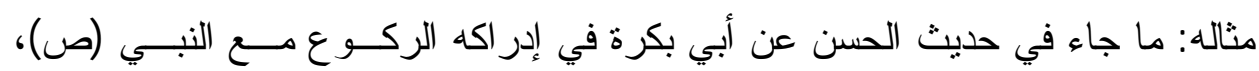

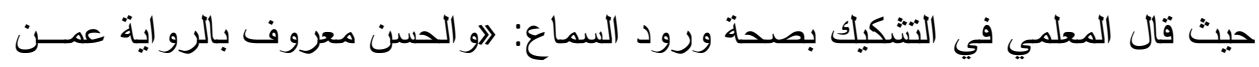

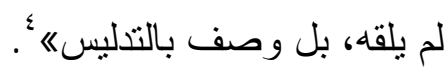
ع. . عادة الر اوي بالتساهل في التصريح بالتحديث على بلى وجه التأويل .

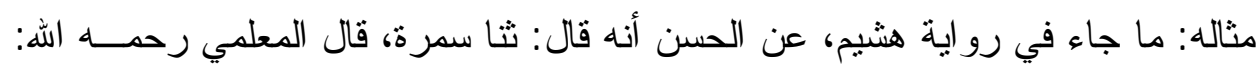

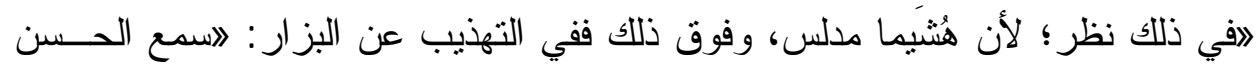

ا رسالة القبلة وقضاء الحاجة، آثار الثيخ العلامة عبد الرحمن بن يحيي المعلمي اليماني (1/ / ه ه).

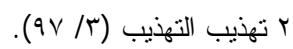

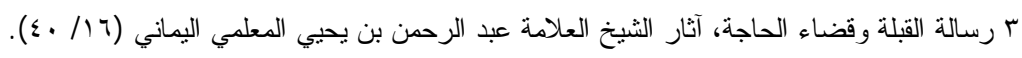

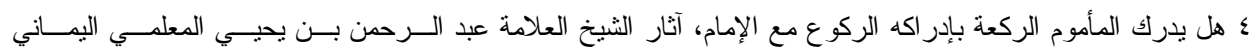




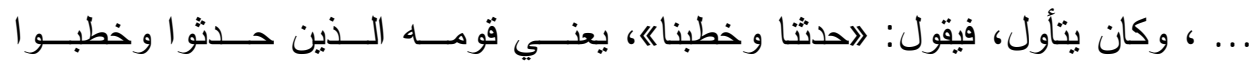

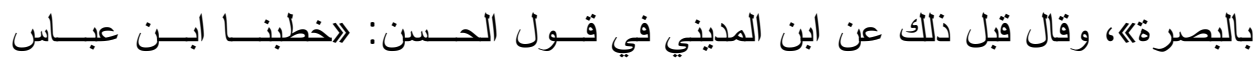

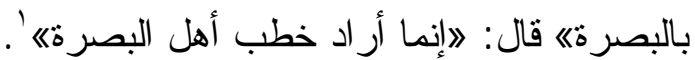

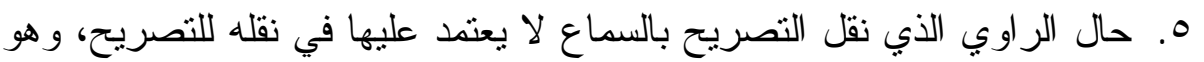
أنواع:

أن يكون من نقل التصريح ضعيفًا، فهذا لا يقبل تصريحه.

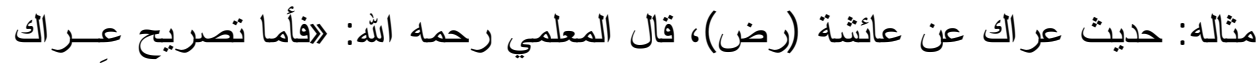

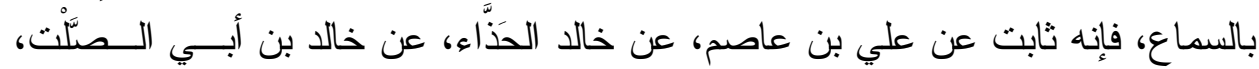

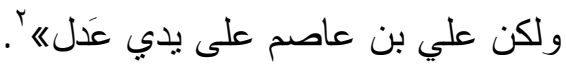
أن يكون من نقل التصريح عُرف أن من عادي عادته الخطأ في ذلك.

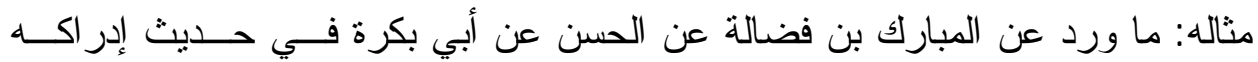

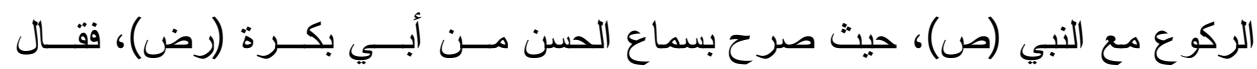

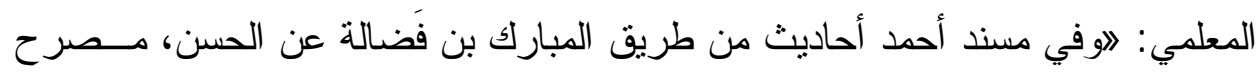

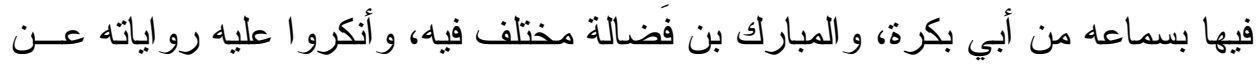

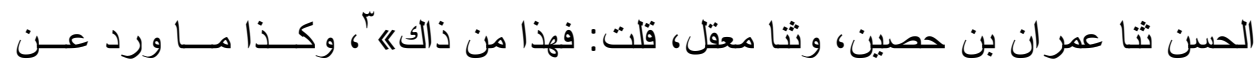

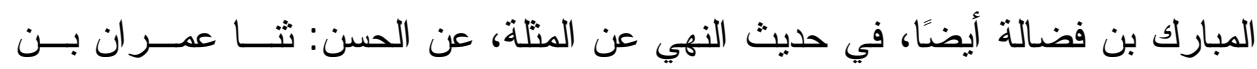

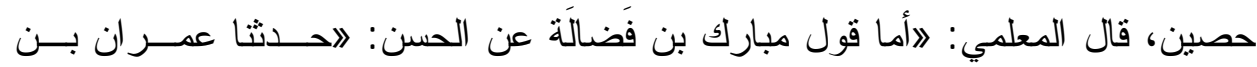

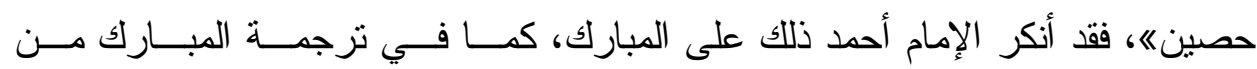

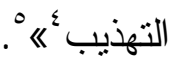

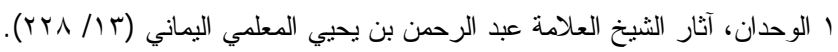

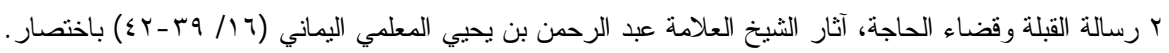

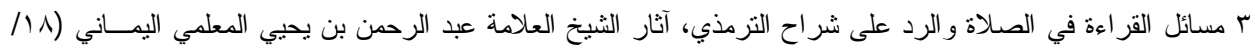


أن يكون من نقل التصريح مُدلسًا فيُخشىى أنه دلَّس الحديث عن ضعيف أخطأ

$$
\text { في التصريح. }
$$

مثاله: ما جاء آنفا من طريق هثيم عن الحسن عن سمرة (رض)، حيث أعله المعلدي بأن هشيمًا مدلس.

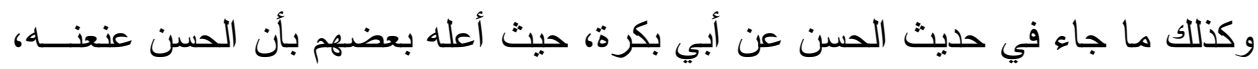

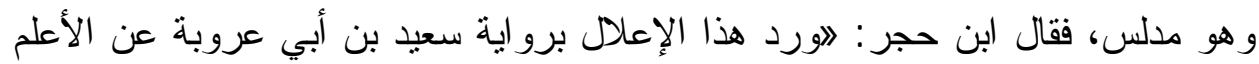

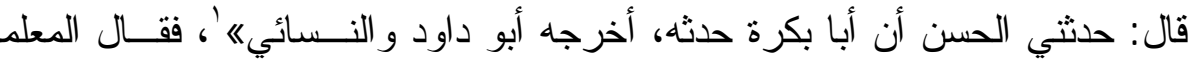

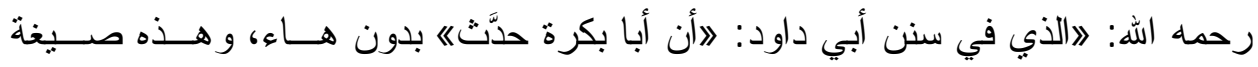

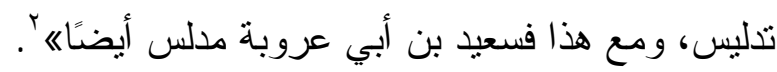

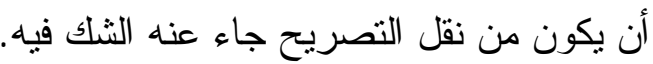

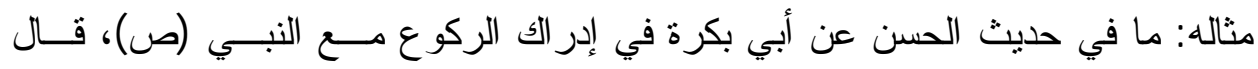

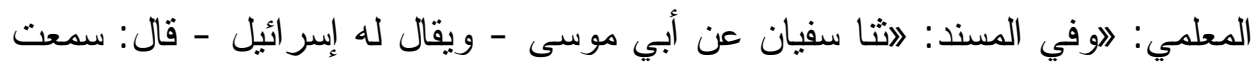

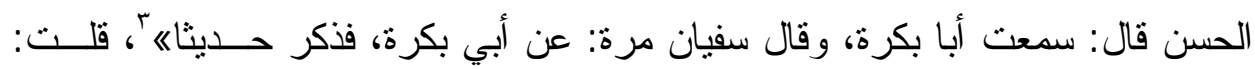

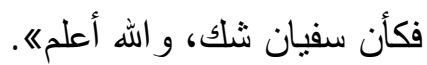
أن يكون من نقل التصريح تغير بأخرة.

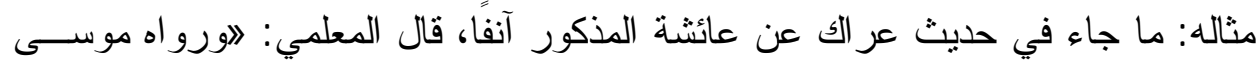

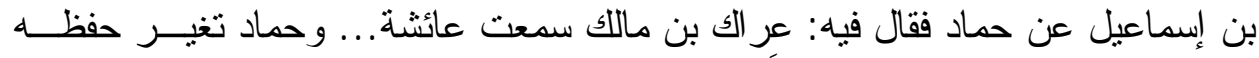

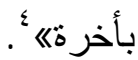

4. ـالفة الر اوي النقة لغيره من الرواة الثقات ممن لم ينقل التصريح بالتحديث.

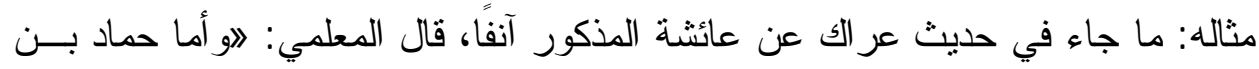

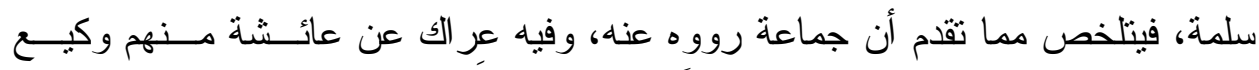

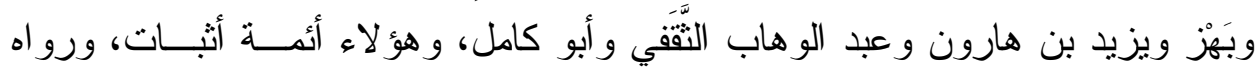

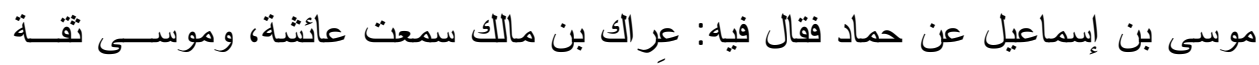

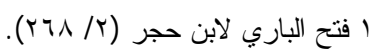

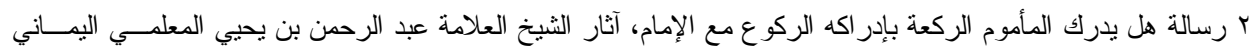

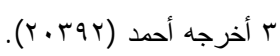

ع رسالة القبلة وقضاء الحاجة، آثار الثيخ العلامة عبد الرحمن بن يحيي المعلمي اليماني (7 / 7 ــ)، باختصار . 


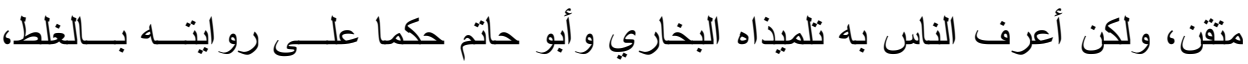

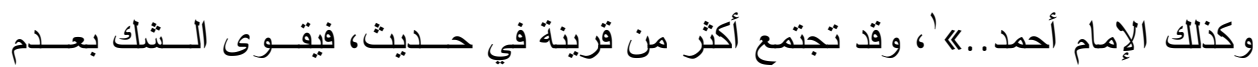

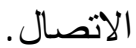

ولم يكتف المعلمي رحمه الله بكثف أخطاء الرواة في التصريح بالتحديث، و إنما اعتنى

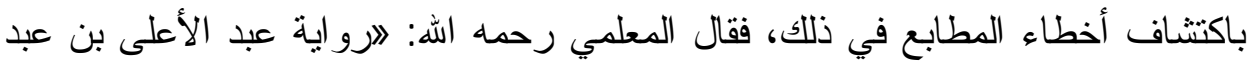

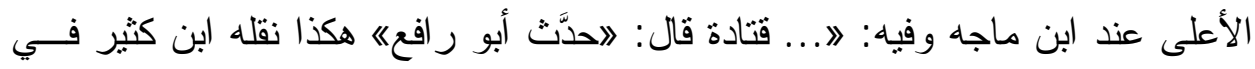

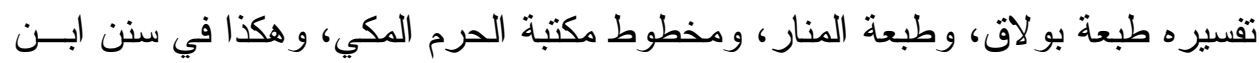

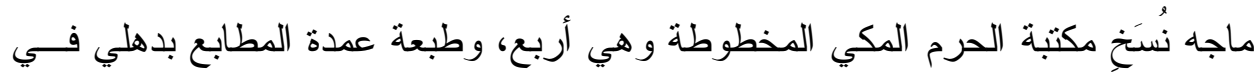

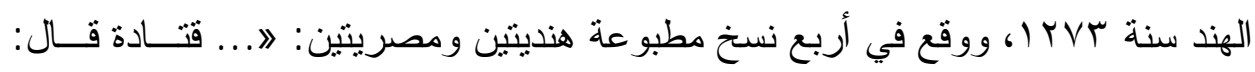

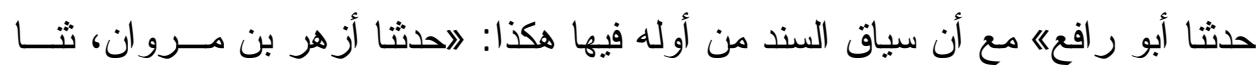

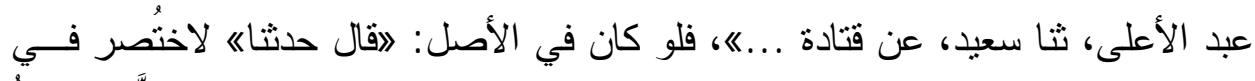

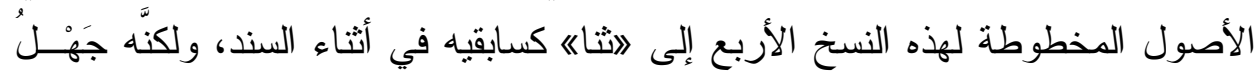

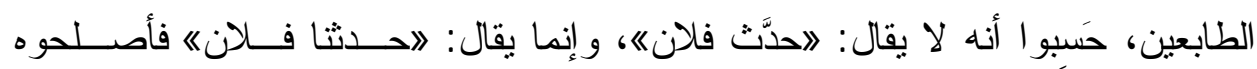

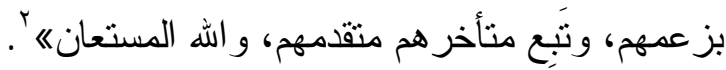

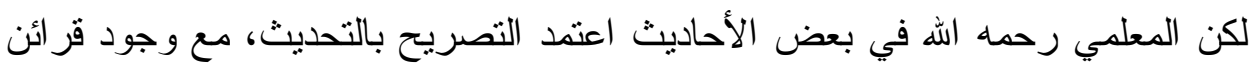
على خطئه، وقد وقع ذللك منه في حديثين:

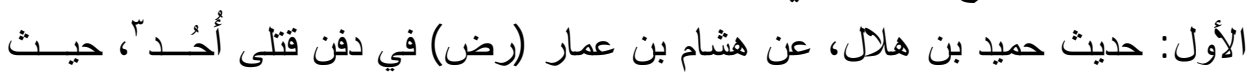
صحح التصريح بالتحديث الوارد في بعض الطرق بين حميد بن هلال وهثام بن عمار بن

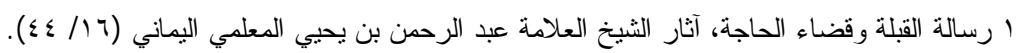

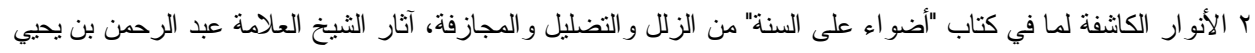

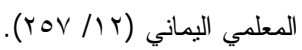

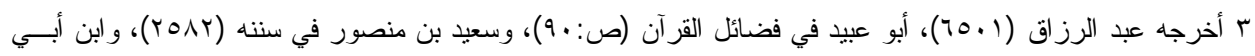

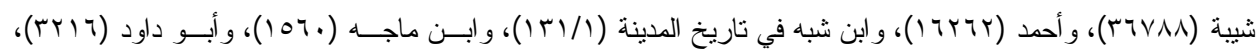

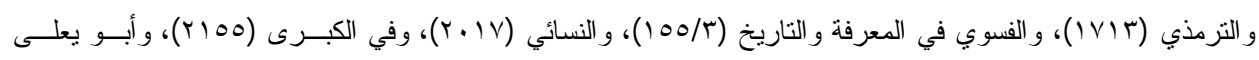

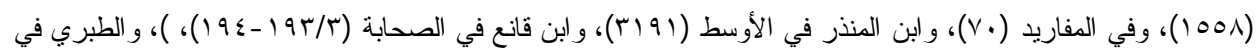

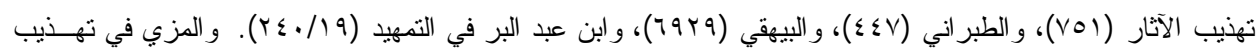


(رض) '، مع أن أبا حاتم ذكر أن حميدًا عن هشام مرسل، ووُجدت بين حميد بن هلال

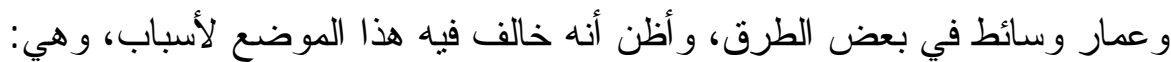

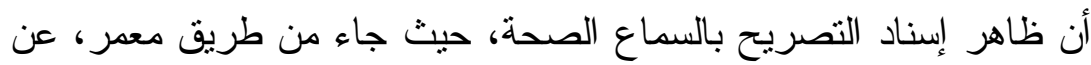

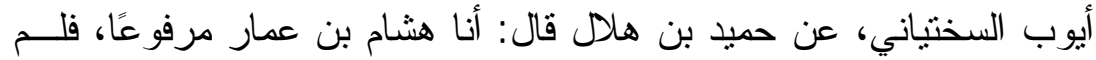

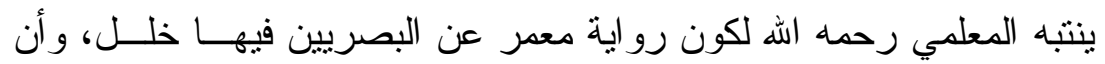
بقية تلاميذ أيوب السختياني لم بنقلو التصريح. أن هذا الحديث جاء في كتاب الوحدان وقد ألفه في الهند، ولعله في السنوات لاتهوات

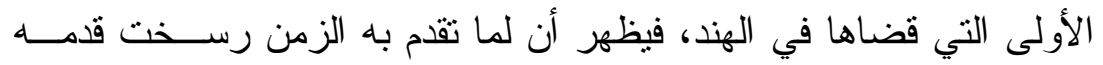

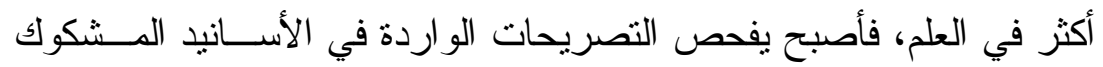
في اتصالها، و الله أعلم. الثاني: حديث يحيى بن جابر الطائي، عن المقدام بن معدي كرب مرفوعًا: لاهـــا مــأ

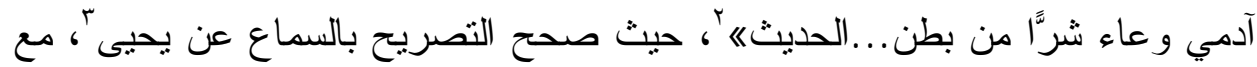

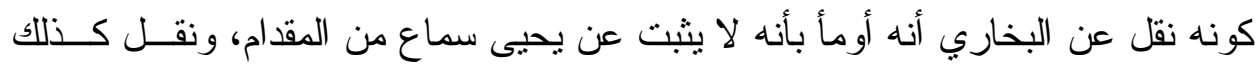

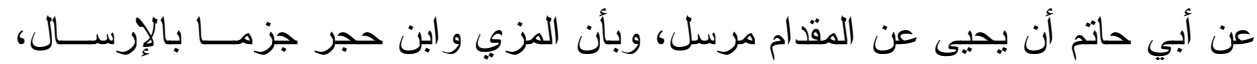

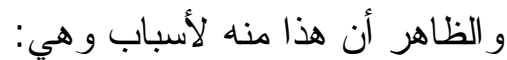
الاعتماد على أن ظاهر الإسناد الوارد في التصريح بالتهديث الصحة؛

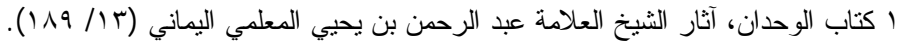

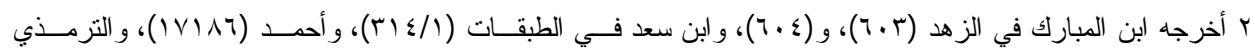

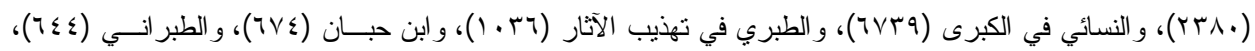

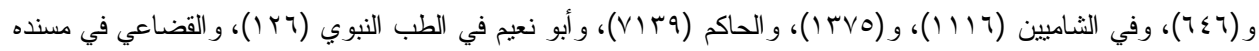

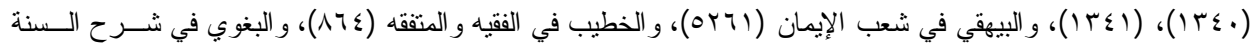

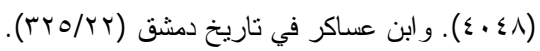

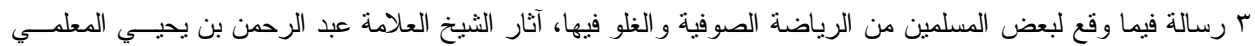

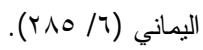

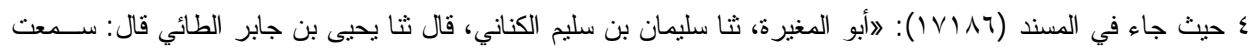

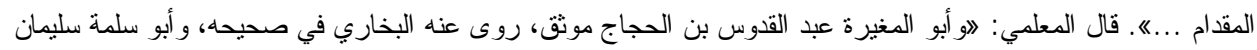
بن سليم موثق أيضًا، ويحيى بن جابر موثقه ، رسالة فيما وقع لبعض المسلمين من الرياضة الصوفية والغلو فيها، آثار الثنيخ

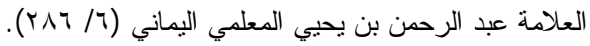


ثبوت المعاصرة بين يحيى و المقدام، بالاعتماد على كونهما في بلد وو احد، وبين

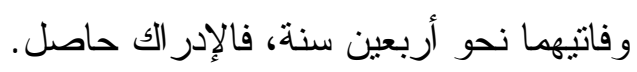

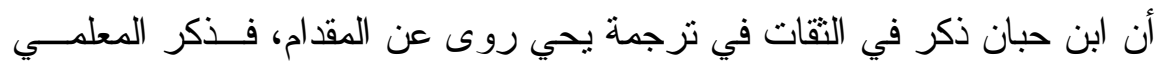
أن هذا منه بمعنى الحكم بسماعه من المقدام' .

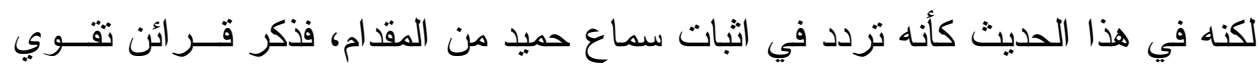

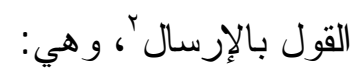
أن يحيى كثير الإرسال عن الصحابة الذين لم يدركهم.

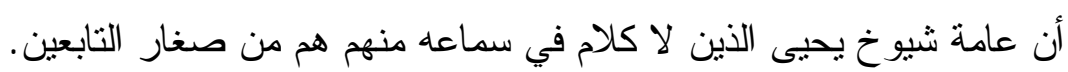

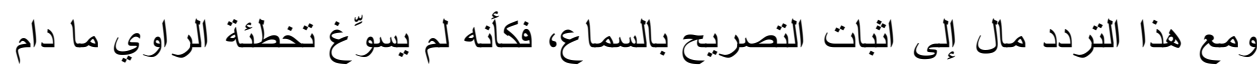
ثقة بلا دليل، و الله أعلم . مدال

ا رسالة فيما وقع لبعض المسلمين من الرياضة الصوفية والغلو فيها، آثار الثيخ العلامة عبد الرحمن بن يحبـي المعلــي

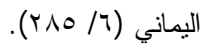
r ب رسالة في ما وقع لبعض المسلمين من الرياضة الصوفية والغلو فيها، آثار الثيخ العلامة عبد الرحمن بن يحيي المعلــي

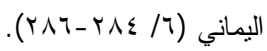


